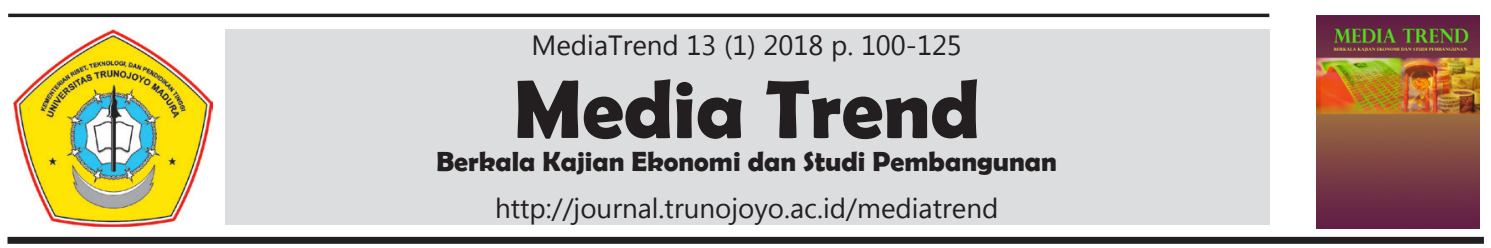

\title{
Keterkaitan Ketersediaan Anugerah Lokal Dengan Ketimpangan Antar Wilayah Pada Sektor Pertanian Di Kabupaten Semarang
}

\author{
Lyra Bumantara Syarif ${ }^{*}$ \\ ${ }^{1}$ Badan Perencanaan, Penelitian dan Pengembangan (Barenlitbangda) Kabupaten Semarang
}

\section{Informasi Artikel \\ Sejarah artikel: \\ Diterima Februari 2018 \\ Disetujui Februari 2018 \\ Dipublikasikan Maret \\ 2018}

\section{Keywords:}

Local Endowments,

Disparities Between

Regions,

Agricultural Sector

\begin{abstract}
A B S T R ACT
Agriculture as the oldest economic sector in the world is a potential catalyst to reduce disparities between regions, especially in developing countries which are the livelihoods of the citizens are mostly very much dependent in agricultural sector. Nevertheless the efforts to make the agricultural sector as a catalyst for reducing the disparities between regions in developing countries until now is constrained with the productivity level of agricultural sector that is still low due to the high dependency on the availability of local endowments. As for with low productivity level of the agricultural sector surely will be impacted on the extent of the disparities between regions. Hence, this research trying to analyze how big the influence of local endowments (which is represented with the size of farmland and the amount of agricultural labour), are affecting the disparity of agricultural sector between regions in Semarang Regency that will be focused on years 2008-2011.
\end{abstract}




\section{Pendahuluan}

Ketimpangan antar wilayah merupakan permasalahan mendasar yang umum ditemui dalam proses pembangunan suatu negara. Bahkan di negara-negara yang sudah tergolong maju sekalipun juga tidak dapat terlepas dari problematika ini. Hanya saja, di negara maju derajat/taraf ketimpangan antar wilayah secara umum relatif lebih rendah daripada yang terjadi di negara-negara berkembang.

Pertanian sebagai salah satu sektor perekonomian dapat diperankan sebagai katalisator yang sangat potensial untuk mengurangi ketimpangan antar wilayah, khususnya di negara-negara sedang berkembang. Hal ini dimungkinkan mengingat di mayoritas negara berkembang sektor pertanian merupakan basis utama mata pencaharian penduduk, sehingga apabila kinerja agregatnya dapat diberdayakan secara optimal tentunya akan sangat berpengaruh signifikan meningkatkan pertumbuhan ekonomi dan mengurangi kemiskinan di setiap wilayah. Dengan demikian, tujuan pembangunan untuk mewujudkan pertumbuhan ekonomi yang setinggi-tingginya dapat tercapai dengan tetap berpegang teguh pada asas pemerataan dan keadilan.

Akan tetapi upaya untuk menjadikan sektor pertanian sebagai katalis dalam mengurangi ketimpangan antar wilayah di negara berkembang hingga saat ini masih menemui kendala akibat tingkat produktivitas sektor pertanian di negara-negara berkembang yang pada umumnya masih rendah. Rendahnya tingkat produktivitas ini diakibatkan karena masih tingginya tingkat ketergantungan produksi pertanian di negara-negara berkembang terhadap ketersediaan anugerah lokal (local endowments) sehingga menyebabkan proses akselerasi dalam peningkatan produksi pertanian di wilayah-wilayah negara berkembang berjalan dengan lambat dan bahkan menunjukkan kecenderungan semakin menurun.
Ketergantungan produksi sektor pertanian di Kabupaten Semarang terhadap ketersediaan anugerah lokal (local endowments) dapat diidentifikasi dari masih tingginya kebutuhan akan ketersediaan luas lahan dan tenaga kerja untuk dapat berproduksi dalam sektor pertanian. Data BPS pada tahun 2011 mencatat luas lahan pertanian di Kabupaten Semarang mencapai $63,61 \%$ dari total luas wilayah. Pun demikian halnya pula dengan kebutuhan akan ketersediaan tenaga kerja dalam jumlah besar untuk dapat berproduksi, dimana data BPS tahun 2011 mencatat rasio penyerapan tenaga kerja pada sektor pertanian di Kabupaten Semarang mencapai $35,89 \%$ dari total penyerapan tenaga kerja pada seluruh sektor lapangan usaha. Rasio ini merupakan yang tertinggi jika dibandingkan dengan rasio penyerapan tenaga kerja pada sektor lapangan usaha lainnya.

Namun demikian, meskipun didukung dengan tingkat penggunaan lahan dan penyerapan tenaga kerja tertinggi ternyata sektor pertanian di Kabupaten Semarang justru sangat lemah dalam produktivitas. Kondisi ini tercermin dari perhitungan PDRB per kapita menurut lapangan usaha pada tahun 2011 secara makro di tingkat kabupaten yang menunjukkan bahwa sektor pertanian menghasilkan produktivitas per kapita terkecil jika dibandingkan dengan seluruh sektor lapangan usaha lainnya.

Rendahnya tingkat produktivitas sektor pertanian yang berdampak terhadap rendahnya derajat/taraf ketimpangan antar wilayah pada sektor pertanian di Kabupaten Semarang nampaknya diakibatkan karena sektor pertanian yang dikembangkan para petani cenderung bersifat subsisten dan sedikit pertanian keluarga campuran berskala kecil, sehingga peningkatan produktivitas pertanian hanya bertumpu pada dua faktor produksi utama yang juga merupakan bagian dari anugerah lokal (local endowments), yaitu lahan dan tenaga kerja. 
Tabel 1

PDRB Per Kapita Menurut Lapangan Usaha Di Kabupaten Semarang Tahun 2011

\begin{tabular}{clr}
\hline No. & Sektor Lapangan Usaha & PDRB per Kapita* (Rp.) \\
\hline 1. & Listrik, Gas, \& Air & $40.548 .410,94$ \\
\hline 2. & Keuangan, Persewaan \& Jasa & $25.228 .720,82$ \\
& Perusahaan & $24.333 .580,02$ \\
\hline 3. & Industri Pengolahan & $13.904 .447,06$ \\
\hline 4. & Perdagangan, Hotel \& Restoran & $7.319 .696,08$ \\
\hline 5. & Konstruksi & $7.279 .332,46$ \\
\hline 6. & Angkutan \& Komunikasi & $7.115 .264,80$ \\
\hline 7. & Pertambangan dan Penggalian & $6.925 .030,10$ \\
\hline 8. & Jasa-jasa & $5.145 .271,47$ \\
\hline 9. & Pertanian \\
\hline Sumber : BPS Kab. Semarang, Kabupaten Dalam Angka dan PDRB \\
\multicolumn{2}{c}{ Sektoral Tahun 2012 (diolah) } \\
\hline *Dihitung berdasarkan harga konstan tahun 2000
\end{tabular}

Berdasarkan latar belakang permasalahan tersebut, maka melalui penelitian ini kami mencoba untuk menganalisis seberapa besar ketersediaan anugerah lokal (local endowments) yang diwakili oleh luas lahan pertanian dan jumlah tenaga kerja sektor pertanian dapat mempengaruhi terjadinya ketimpangan wilayah pada sektor pertanian di Kabupaten Semarang yang cakupan bahasannya akan difokuskan pada tahun 2008-2011.

Adapun bentuk rumusan permasalahan penelitian ini adalah sebagai berikut (1) Apakah perbedaan luas lahan pertanian dan jumlah tenaga kerja sektor pertanian secara bersama-sama berpengaruh terhadap ketimpangan antar wilayah pada sektor pertanian di Kabupaten Semarang dalam kurun waktu 2008-2011. (2) Apakah perbedaan luas lahan pertanian secara parsial berpengaruh terhadap ketimpangan antar wilayah pada sektor pertanian di Kabupaten Semarang dalam kurun waktu 2008-2011. (3) Apakah perbedaan jumlah tenaga kerja sektor pertanian secara parsial berpengaruh terhadap ketimpangan antar wilayah pada sektor pertanian di Kabupaten Semarang dalam kurun waktu 2008-2011.

Sesuai dengan rumusan permasahan penelitian di atas, maka dapat diformulasikan 3 (tiga) bentuk hipotesis yang menjadi landasan untuk melakukan pembahasan dan analisis dalam penelitian ini, yaitu : (H1) Diduga perbedaan luas lahan pertanian dan jumlah tenaga kerja sektor pertanian secara bersama-sama berpengaruh terhadap ketimpangan antar wilayah pada sektor pertanian di Kabupaten Semarang dalam kurun waktu 20082011. (H2) Diduga perbedaan luas lahan pertanian secara parsial berpengaruh terhadap ketimpangan antar wilayah pada sektor pertanian di Kabupaten Semarang dalam kurun waktu 2008-2011. (H3) Diduga perbedaan jumlah tenaga kerja sektor pertanian secara parsial berpengaruh terhadap ketimpangan antar wilayah pada sektor pertanian di Kabupaten Semarang dalam kurun waktu 2008-2011.

Munculnya konsep ketimpangan antar wilayah pada awalnya bermula dari hipotesis Simon Kuznets tentang kurva $U$ terbalik (inverted $U$ curve) yang menggambarkan ketimpangan distribusi pendapatan di suatu negara. Dalam hipotesis tersebut, Simon Kuznets (Kuncoro, 2010:96) berpendapat bahwa "di saat permulaan pembangunan dimulai, distribusi pendapatan akan makin tidak merata, namun setelah mencapai suatu tingkat pembangunan tertentu, distribusi pendapatan makin merata". 
Menurut Hipotesa Neo-klasik, pada permulaan proses pembangunan suatu negara, ketimpangan pembangunan antar wilayah cenderung meningkat. Proses ini akan terjadi sampai ketimpangan tersebut mencapai titik puncak. Setelah itu, bila proses pembangunan terus berlanjut, maka secara berangsur-angsur ketimpangan pembangunan antar wilayah tersebut akan menurun.

Ketimpangan antar wilayah dapat dipengaruhi oleh banyak faktor. Para ilmuwan ekonomi memiliki pendapat yang berbeda mengenai faktor-faktor berpengaruh yang menyebabkan terjadinya ketimpangan antar wilayah. $\mathrm{Na}$ mun demikian perbedaan pendapat tersebut lebih disebabkan karena perbedaan fokus studi ketimpangan antar wilayah yang mereka lakukan. Berikut ini adalah beberapa pendapat dari sejumlah ilmuwan ekonomi mengenai faktor-faktor penyebab terjadinya ketimpangan antar wilayah :

Menurut Sjarizal (2008:104), "secara alamiah ketimpangan antar wilayah pada dasarnya disebabkan oleh adanya perbedaan kandungan sumberdaya alam dan kondisi demografi yang dimiliki oleh masing-masing wilayah". Akibat dari perbedaan ini, kemampuan suatu wilayah dalam mendorong proses pembangunan juga menjadi berbeda. Selain akibat perbedaan kandungan sumberdaya alam dan kondisi demografi, Sjafrizal (2008:119120) berpendapat bahwa ketimpangan antar wilayah juga dapat disebabkan oleh sejumlah faktor lain seperti kurang lancarnya mobilitas barang dan jasa, konsentrasi kegiatan ekonomi wilayah, dan alokasi dana pembangunan antar wilayah.

Williamson (Adisasmita, 2013:76) mengemukakan 4 (empat) faktor yang mendasari disparitas/ketimpangan antar wilayah pada konteks pendapatan regional, yaitu : a) Sumber daya alam yang dimiliki, b) Perpindahan tenaga kerja, c) Perpindahan modal, dan d) Kebijakan pemerintah. Sementara Subandi (2008:117-119) yang berfokus pada studi pembangunan ekonomi daerah berpendapat ketimpangan antar wilayah setidaknya disebabkan oleh 4 (empat) faktor, yaitu : a) Ketimpangan pembangunan sektor industri, b) Tingkat mobilitas faktor produksi yang rendah, c) Perbedaan demografis, dan d) Kurang lancarnya perdagangan antar daerah.

Sementara itu Tambunan (2001:190-199) melalui sebuah studi komparasi ekonomi regional mengemukakan bahwa faktor-faktor utama yang menyebabkan terjadinya ketimpangan ekonomi regional adalah : a) Konsentrasi kegiatan ekonomi wilayah, b) Alokasi investasi, c) Tingkat mobilitas faktor produksi yang rendah antar wilayah, d). Perbedaan sumber daya alam antar wilayah, e) Perbedaan demografis antar wilayah, dan f) Pola Perdagangan antar daerah. Mirip dengan pendapat Tambunan, Emilia dan Imelia (2006:46-49) mengemukakan setidaknya terdapat 5 (lima) faktor yang menyebabkan terjadinya ketimpangan pembangunan ekonomi antar wilayah, yaitu : a) Konsentrasi kegiatan ekonomi wilayah, b) Alokasi investasi, c) Tingkat mobilitas dan faktorfaktor produksi yang rendah antar wilayah, d) Perbedaan sumberdaya alam antar wilayah, e) Perbedaan kondisi demografis antar wilayah, dan e) Kurang lancarnya perdagangan antar wilayah.

Berdasarkan sintesis pendapat para ahli yang telah diuraikan di atas, dapat diperoleh satu kesimpulan bahwa perbedaan sumber daya alam dan perbedaan kondisi demografis merupakan 2 (dua) faktor yang paling dominan menyebabkan terjadinya ketimpangan antar wilayah.

\section{Pengaruh Perbedaan Sumber Daya Alam Terhadap Ketimpangan Antar Wilayah}

Adanya perbedaan kandungan
sumber daya alam jelas akan mempengaruhi ketimpangan antar wilayah karena erat kaitannya dengan kegiatan produksi suatu daerah. Menurut Sjafrizal 
(2008:117-118), pengaruh perbedaan sumber daya alam terhadap ketimpangan antar wilayah dapat dijelaskan sebagai berikut :

Daerah dengan kandungan sumber daya alam cukup tinggi akan dapat memproduksi barang dan jasa tertentu dengan biaya relatif murah dibandingkan dengan daerah lain yang mempunyai kandungan sumber daya alam lebih rendah. Kondisi ini mendorong pertumbuhan ekonomi daerah bersangkutan menjadi lebih cepat. Sedangkan daerah lain yang mempunyai kandungan sumber daya alam lebih rendah hanya akan dapat memproduksi barang dan jasa dengan biaya produksi lebih tinggi sehingga daya saingnya menjadi lemah. Kondisi tersebut selanjutnya menyebabkan pula daerah yang bersangkutan cenderung mempunyai pertumbuhan ekonomi yang lebih lambat. Dengan demikian, terlihat bahwa perbedaan kandungan sumber daya alam dapat mendorong terjadinya ketimpangan ekonomi antar wilayah yang lebih tinggi pada suatu negara.

Adapun Sjafrizal (2008:117) mendeskripsikan bahwa yang dimaksud dengan perbedaan kandungan sumber daya alam dalam konteks ini adalah meliputi perbedaan pada ketersediaan sumber daya energi dan mineral, seperti minyak bumi, gas alam, dan batubara; serta juga meliputi perbedaan ketersediaan lahan subur pada sektor pertanian.

\section{Pengaruh Perbedaan Kondisi Demo- grafis Terhadap Ketimpangan Antar Wilayah}

Kondisi demografis erat kaitannya dengan ketimpangan antar wilayah dikarenakan hal tersebut akan berpengaruh terhadap produktivitas kerja masyarakat di suatu daerah. Menurut Sjafrizal (2008:117-118), mekanisme terjadinya ketimpangan antar wilayah yang diakibatkan oleh pengaruh perbedaan kondisi de- mografis dapat dijelaskan sebagai berikut :

Daerah dengan kondisi demografis yang baik akan cenderung mempunyai tingkat produktivitas yang lebih tinggi. Kondisi ini selanjutnya akan mendorong pula peningkatan investasi ke daerah yang bersangkutan sehingga akan cenderung pula meningkatkan penyediaan lapangan kerja dan pertumbuhan ekonomi daerah tersebut. Sebaliknya, bila pada suatu daerah tertentu kondisi demografisnya kurang baik maka hal ini akan menyebabkan relatif rendahnya tingkat produktivitas kerja masyarakat setempat yang cenderung menimbulkan kondisi kurang menarik investor sehingga pertumbuhan ekonomi daerah bersangkutan menjadi lebih rendah.

Adapun yang dimaksud dengan perbedaan kondisi demografis menurut Sjafizal (2008:118) adalah meliputi perbedaan tingkat pertumbuhan dan struktur kependudukan, perbedaan tingkat pendidikan dan kesehatan, perbedaan kondisi ketenagakerjaan dan perbedaan dalam tingkah laku dan kebiasaan serta etos kerja yang dimiliki masyarakat.

\section{Pengaruh Ketersediaan Lahan dan Tenaga Kerja Terhadap Ketimpangan Antar Wilayah \\ Menurut pendapat Sjafrizal} (2008:117-119), lahan dan tenaga kerja merupakan bagian dari indikator faktor sumber daya alam dan faktor demografis yang merupakan dua faktor utama penyebab terjadinya ketimpangan antar wilayah. Dalam hal ini, lahan merupakan indikator yang mewakili faktor sumber daya alam, sedangkan tenaga kerja merupakan indikator yang mewakili faktor demografis.

Sementara jika ditinjau dari sudut pandang faktor produksi, Machfudz (2007:96) berpendapat bahwa faktor produksi yang paling utama pada seluruh unit produsen adalah lahan dan tenaga kerja, oleh karena itu keduanya sering disebut dengan input utama (mother is in- 
put). Mengingat peranannya yang sangat krusial sebagai input utama tersebut, maka perbedaan ketersediaan lahan dan tenaga kerja merupakan faktor pemicu terjadinya ketimpangan pendapatan. Hal ini sebagaimana diutarakan oleh Charles-Coll (2011:19-20) dalam pendapatnya sebagai berikut :

Mungkin satu penyebab utama terjadinya ketimpangan selama bertahun-tahun adalah konsentrasi lahan. Efek dari fenomena tersebut dapat dilacak berdasarkan sejarah disetiap sudut dunia dan juga melalui sejarah setiap negara.

Distribusi lahan sebagai sumber dari ketimpangan adalah umumnya berhubungan dengan masyarakat pedesaan, dimana produksi dan pembangunan kesejahteraan sangat berhubungan erat dengan kegiatan pertanian.

Pasar tenaga kerja memainkan peran yang mendasar dalam penentuan kadar ketimpangan, meskipun tidak selalu menjadi penyebab utama, tetapi banyak berperan sebagai efek perantara keadaan/permasalahan lain yang mungkin mempengaruhi permintaan atau penawaran dalam pasar tenaga kerja.

Lebih lanjut, perbedaan ketersediaan input produksi lahan dan tenaga kerja dinilai akan berpotensi menimbulkan ketimpangan antar wilayah karena dapat menyebabkan terjadinya kesenjangan kinerja suatu daerah dalam memproduksi barang dan jasa. Asumsi ini didasarkan atas pendapat Soegiarto dan Mardyono dan juga pendapat Nijkamp. Soegiarto dan Mardyono (2011:2) menyatakan bahwa "semakin baik faktor produksi yang tersedia, baik secara kuantitas maupun kualitas maka akan juga semakin baik hasil produksinya". Namun demikian, sebaliknya "kekurangan dalam ketersediaan faktorfaktor produksi akan dapat mengakibatkan kinerja lebih rendah pada suatu daerah" (Nijkamp, 2009:267).
Dengan demikian, melalui sintesis beberapa pendapat diatas dapat diasumsikan bahwa kekurangan pada ketersediaan input utama, yaitu lahan dan tenaga kerja akan mengkibatkan terjadinya ketimpangan pendapatan yang secara aggregat menyebabkan kinerja yang lebih rendah disuatu daerah sehingga dapat memicu terjadinya ketimpangan antar wilayah. Adapun jika mengacu kepada pendapat Charles-Coll dapat diperkirakan bahwa faktor ketersediaan lahan dinilai memiliki pengaruh yang sangat signifikan menimbulkan terjadinya ketimpangan antar wilayah. Sedangkan faktor ketersediaan tenaga kerja meskipun juga dinilai berpengaruh, namun tidak selalu menjadi faktor utama yang menyebabkan terjadinya ketimpangan antar wilayah.

Terkait dengan produktivitas sektor pertanian di negara-negara berkembang Sukirno (1985:155-156) berpendapat bahwa sektor pertanian merupakan pusat kegiatan ekonomi di sebagian besar negara berkembang. Namun demikian, tingkat produktivitas kegiatan pertanian di negara-negara berkembang umumnya masih rendah sehingga menyebabkan rendahnya pendapatan petani yang berakibat sulitnya negara-negara berkembang dalam meningkatkan produksi pertanian perkapita penduduknya.

Menurut Todaro dan Smith (2006:529), rendahnya produktivitas pertanian di negara berkembang lebih disebabkan karena karakteristik sektor pertanian di negara-negara berkembang yang pada umumnya masih berada pada taraf pertanian subsisten, dimana lahan dan tenaga kerja adalah faktor-faktor produksi utama yang dimiliki oleh para petani. Ketergantungan akan ketersediaan lahan dan tenaga kerja ini tentunya akan mengakibatkan produktivitas pertanian menjadi sulit untuk ditingkatkan secara signifikan mengingat pertambahan jumlah tenaga kerja tidak selalu diimbangi dengan ketersediaan lahan pertanian yang notabene luasannya cenderung tetap. 
Pada sisi lain, Todaro dan Smith (2006:505) mencermati adanya penurunan produktivitas sektor pertanian terhadap pembentukan Pendapatan Nasional Bruto (GNI) di negara-negara sedang berkembang. Di saat sektor industri manufaktur dan sektor perdagangan terus mengalami pertumbuhan output secara signifikan, sektor pertanian justru mengalami stagnasi sehingga andil output sektor pertanian dalam PNB secara keseluruhan terus menurun.

Gejala menurunnya kontribusi pertanian terhadap pembentukan Pendapatan Nasional di negara-negara berkembang pada umumnya disebabkan karena terjadinya kejenuhan produksi dalam sektor pertanian yang mengikuti hukum perolehan hasil yang semakin menurun (law of diminishing returns). Menurut Todaro dan Smith (2006:79), rendahnya kinerja produksi sektor pertanian di negara berkembang diakibatkan karena produktivitas pertanian di negara-negara tersebut mengikuti berlakunya prinsip produktivitas marjinal yang semakin menurun (diminishing marginal productivity). Oleh Todaro dan Smith (2006:79), kaidah/ mekanisme berlakunya prinsip ini dapat dijelaskan sebagai berikut :

Jika terjadi peningkatan jumlah salah satu faktor variabel (faktor produksi yang jumlah ketersediaan dan pemakaiannya bisa berubah-ubah, seperti faktor tenaga kerja), sedangkan kuantitas faktor lainnya tidak berubah (seperti faktor modal, tanah, dan bahan baku), maka setelah melewati suatu titik tertentu, tambahan marjinal produk (output) yang bersumber dari penambahan faktor variabel tersebut akan menurun. Atas dasar prinsip ini, kita dapat menebak bahwa rendahnya tingkat produktivitas tenaga kerja di negara-negara dunia ketiga disebabkan oleh kurangnya faktor-faktor input "komplementer" (faktor produksi selain tenaga kerja) seperti modal dan atau kecakapan manajemen yang berpengalaman.

Dengan demikian, jika melihat kondisi faktual bahwa mayoritas petani di negara berkembang adalah petani kecil yang miskin sumber daya produksi maka dapat diasumsikan "dengan semakin banyaknya orang-orang yang mengerjakan sebidang lahan yang sama akan berakibat pada tingkat produktivitas marjinal (dan rata-ratanya) semakin menurun" (Todaro dan Smith, 2006:509).

Adapun gejala diminishing returns ataupun diminishing marginal productivity di negara berkembang adalah sesuai dengan teori model dua sektor pembangunan yang digagas oleh Arthur Lewis (Kuncoro, 2010:110-111). Terjadinya diminishing returns ataupun diminishing marginal productivity menurut teori tersebut adalah diakibatkan adanya surplus tenaga kerja pada sektor pertanian. Dalam teorinya Lewis mengasumsikan bahwa di daerah perdesaan, sebagai tempat tinggalnya mayoritas penduduk negara berkembang, dengan corak perekonomian tradisionalnya mengalami surplus tenaga kerja. Surplus tersebut erat kaitannya dengan basis utama perekonomian tradisional yang tingkat hidup masyarakatnya berada pada kondisi subsisten. Hal ini ditandai dengan nilai produk marjinal (marginal product) tenaga kerja yang bernilai nol. Artinya fungsi produksi pada sektor pertanian telah sampai pada tingkat berlakunya law of diminishing return.

Kondisi tersebut menunjukkan bahwa penambahan input variabel, dalam hal ini tenaga kerja justru akan menurunkan total produksi yang ada. Disisi lain, pengurangan jumlah tenaga kerja yang dipekerjakan di sektor pertanian tidak akan mengurangi tingkat produksi yang ada, akibat proporsi input variabel tenaga kerja yang terlalu besar. Dalam perekonomian semacam ini, pangsa semua pekerja terhadap output yang dihasilkan adalah sama. Melalui uraian di atas dapat diketahui bahwa meskipun berperan seba- 
gai pusat kegiatan ekonomi masyarakat, namun tingkat produktivitas sektor pertanian di sebagian besar negara berkembang pada umumnya masih rendah. Rendahnya produktivitas ini dapat disebabkan karena karakteristik sektor pertanian di negaranegara berkembang umumnya masih berada pada taraf pertanian subsisten, dimana lahan dan tenaga kerja adalah faktor-faktor produksi utama yang dimiliki oleh para petani.

Dengan hanya bertumpu pada ketersediaan lahan dan tenaga kerja tentunya akan sulit untuk meningkatkan produktivitas sektor pertanian secara signifikan mengingat pertambahan jumlah tenaga kerja tidak selalu diimbangi dengan ketersediaan lahan pertanian yang notabene luasannya cenderung tetap.

Pada sisi lain, sektor pertanian di negara-negara berkembang juga menunjukkan gejala penurunan kontribusi terhadap pembentukan Pendapatan Nasional. Penurunan kontribusi ini dapat dimungkinkan terjadi karena produksi sektor pertanian di negara-negara berkembang telah mencapai titik jenuh sehingga produktivitas pertanian di negara-negara tersebut mengikuti berlakunya prinsip produktivitas marjinal yang semakin menurun (diminishing marginal productivity) sebagai akibat ketersediaan input tenaga kerja cenderung terus bertambah tanpa diikuti dengan penambahan input lainnya. Dengan kondisi yang demikian maka produksi sektor pertanian di negaranegara berkembang dapat diasumsikan mengikuti hukum perolehan hasil yang semakin menurun (law of diminishing returns).

\section{Metode Penelitian}

Populasi, Sampel, dan Teknik Sampling

Populasi dalam penelitian ini mencakup sektor pertanian di 19 (sembilan belas) kecamatan se-Kabupaten Semarang selama periode tahun 20082011. Agar dapat menggambarkan kondisi sebenarnya secara relatif presisi maka penarikan sampel penelitian akan dilakukan melalui metode non-probability sampling dengan menggunakan teknik sampel jenuh. Atau dengan kata lain seluruh anggota populasi, yaitu sektor pertanian di 19 (sembilan belas) kecamatan se-Kabupaten Semarang selama periode tahun 2008-2011 akan dijadikan sebagai sampel penelitian.

\section{Teknik Pengumpulan Data}

Teknik pengumpulan data dalam penelitian ini akan dilakukan melalui studi dokumentasi/telaah dokumen berdasarkan data-data sekunder untuk periode tahun 2008-2011 yang bersumberkan dari publikasi resmi terbitan Kantor Badan Pusat Statistik (BPS) Kabupaten Semarang.

Adapun secara khusus, untuk merepresentasikan ketimpangan antar wilayah pada sektor pertanian maka dalam penelitian ini akan digunakan indikator ekonomi berupa Indeks Entropy Theil sektor pertanian yang dihitung berdasarkan nilai PDRB per kapita sektor pertanian atas dasar harga konstan dengan menggunakan formula dekomposisi Indeks Entropy Theil oleh Sjafrizal (2012:111) sebagai berikut :

$$
T_{d}=\sum_{i=1}^{n} \sum_{j=1}^{n}\left(y_{i j} / Y\right) \log \left[\left(y_{i j} / Y\right) /\left(n_{i j} / N\right)\right]
$$

Dimana Td merupakan total indeks entropy theil sektor pertanian sedangkan yij merupakan PDRB per kapita sektor pertanian kecamatan i di kabupaten j, Y merupakan Jumlah PDRB per kapita sektor pertanian seluruh kecamatan di kabupaten $\mathrm{j}$, nij Jumlah penduduk kecamatan i di kabupaten j dan $\mathrm{N}$ merupakan Jumlah seluruh penduduk kecamatan di kabupaten j.

\section{Teknik Pengolahan Data dan Analisis Data}

Jenis data yang akan digunakan dalam penelitian ini adalah data panel atau 
sering juga disebut sebagai data pooling, yaitu merupakan gabungan antara data runtut waktu (time series) dengan data silang tempat (cross section). Pemilihan data panel sebagai basis analisis dalam penelitian ini didasarkan atas pendapat Purwanto dan Sulistyastuti (2011:22) yang menjelaskan bahwa penggunaan data panel adalah satu solusi di saat seorang peneliti mengalami hambatan keterbatasan data ketika ingin melakukan penelitian silang tempat atau runtut waktu. Di satu sisi apabila penelitiannya diestimasi dengan menggunakan data runtut waktu, maka jumlah observasinya tidak mencukupi. Di sisi lain, apabila penelitiannya diestimasi dengan menggunakan data silang tempat, maka jumlah observasinya terlalu sedikit untuk menghasilkan estimasi yang efisien. Oleh karena itu untuk mengatasi kendala tersebut dapat dilakukan estimasi dengan menggunakan model data panel.

Pengolahan data dalam penelitian ini pada tahap awal dilakukan dengan menggunakan aplikasi Microsoft Excel 2007. Untuk kemudian, setelah diproses ke dalam format data panel, data tersebut diolah lebih lanjut dengan menggunakan bantuan aplikasi Eviews 7.2 melalui pemodelan berdasarkan estimasi persamaan regresi berganda sebagai berikut :

Indekset $=\alpha+\beta_{1}$ Lahan $+\beta_{2}$ Naker $+\varepsilon$

Dimana Indekset merupakan distribusi indeks entropy Theil (indeks ketimpangan) sektor pertanian per kecamatan, a merupakan Nilai koefisien /intercept persamaan, B1 merupakan koefisien variabel luas lahan pertanian, lahan merupakan luas lahan pertanian per kecamatan, $\beta 2$ merupakan koefisien variabel jumlah tenaga kerja sektor pertanian, naker merupakan Jumlah tenaga kerja sektor pertanian per kecamatan, dan $\varepsilon$ merupakan error term/ residual.

Untuk mendapatkan model regresi yang paling tepat sesuai dengan kebutuhan menjawab permasalahan penelitian, maka harus dilakukan pemilihan dan pengujian reliabilitas terhadap model regresi yang dihasilkan. Yaitu melalui serangkaian tahapan pengujian model regresi yang meliputi uji pemilihan model, uji kesesuaian model (goodness of fit test) dan pengujian asumsi klasik. Adapun pengujian reliabilitas model dilakukan dengan menggunakan bantuan aplikasi Eviews 7.2 berdasarkan pilihan derajat signifikansi (a) 5\%.

\section{Hasil dan Pembahasan \\ Gambaran Umum Sistem Perwilayahan di Kabupaten Semarang}

Peraturan Daerah (Perda)

Kabupaten Semarang Nomor 6 Tahun 2011 tentang Rencana Tata Ruang Wilayah Kabupaten Semarang Tahun 2011-2031 menetapkan bahwa pengaturan sistem perwilayahan di Kabupaten Semarang dilakukan dengan cara membagi wilayah Kabupaten Semarang ke dalam SatuanSatuan Wilayah Pengembangan (SWP) sebagai gabungan dari beberapa kecamatan dengan kondisi fisik, sosial dan budaya yang sama serta berada dalam satu pola aliran barang dan jangkauan pelayanan yang sama.

Dalam Perda Nomor 6 Tahun 2011 tersebut, sistem perwilayahan di Kabupaten Semarang dibagi ke dalam 3 (tiga) SWP. SWP-1, yaitu kawasan yang ditetapkan menjadi bagian dari ibukota Kabupaten serta kawasan sekitarnya yang termasuk dalam jangkauan pelayanannya meliputi Kecamatan Ungaran Barat, Ungaran Timur, Bergas, dan Pringapus dengan pusat pengembangan di perkotaan Ungaran. Kecamatan-kecamatan yang tergabung di dalam SWP-1 diarahkan mempunyai fungsi industri, pertanian, pariwisata, pemerintahan, perdagangan dan jasa, fasilitas umum, permukiman; dengan fungsi pusat SWP adalah pelayanan fasilitas umum, perdagangan dan jasa, pusat pemerintahan skala Kabupaten serta permukiman perkotaan. SWP-2, yaitu 
kawasan yang menjadi wilayah pengaruh dari Kota Ambarawa meliputi Kecamatan Ambarawa, Tuntang, Banyubiru, Bandungan, Jambu, Bawen dan Sumowono dengan pusat pengembangan di perkotaan Ambarawa. Kecamatan-kecamatan yang tergabung di dalam SWP2 diarahkan mempunyai fungsi industri, pertanian, pariwisata, perdagangan dan jasa, fasilitas umum, permukiman, perikanan, serta pertahanan dan keamanan; dengan fungsi pusat SWP adalah perdagangan dan jasa agribisnis, serta fasilitas umum. SWP-3, yaitu kawasan yang berada di daerah selatan Kabupaten Semarang; meliputi Kecamatan Suruh, Tengaran, Getasan, Susukan, Kaliwungu, Pabelan, Bancak dan Bringin dengan pusat pengembangan di perkotaan Suruh dan Tengaran. Kecamatan-kecamatan yang tergabung di dalam SWP-3 diarahkan mempunyai fungsi industri, pertanian, pariwisata, dan perikanan; dengan fungsi pusat SWP adalah pusat industri, agribisnis, perdagangan dan jasa, serta pusat fasilitas umum penunjang agropolitan.

\section{Gambaran Umum Kondisi Ketimpangan Antar Wilayah pada Sektor Pertanian di Kabupaten Semarang}

Melalui perhitungan indeks Entropy Theil berdasarkan formula dekomposisi oleh Keil (2010:89) sebagaimana diberikan pada tabel 2, dapat diketahui bahwa derajat ketimpangan antar wilayah yang terjadi pada sektor pertanian di Kabupaten Semarang selama periode tahun 20082011 adalah bersifat rendah (masih dalam batas yang wajar) dikarenakan nilai rataratanya $(0,282)$ masih sangat jauh dari nilai ketimpangan mutlak $(1,00)$.

Adapun dalam menunjukkan pola ketimpangan, perhitungan indeks Entropy Theil menunjukkan potensi ketimpangan cenderung kuat di SWP-1 dan SWP-2, sedangkan pada SWP-3 meskipun menunjukkan potensi ketimpangan namun nilainya sangat kecil. Hal ini dimungkinkan karena pada komparasi antar SWP sebagaimana pada tabel 3, wilayah SWP-3 menghasilkan nilai Indeks Theil Between bernilai minus, yang berarti berpotensi negatif menimbulkan ketimpangan antar wilayah.

Tabel 2

\begin{tabular}{|c|c|c|c|c|c|}
\hline$\frac{\text { Indeks Ent }}{\text { SWP }}$ & nells & Indeks & y Theil & & Rata-Rata \\
\hline & 2008 & 2009 & 2010 & 2011 & Theil \\
\hline SWP-1 & 0,128 & 0,123 & 0,208 & 0,209 & 0,163 \\
\hline SWP-2 & 0,091 & 0,09 & 0,128 & 0,13 & 0,110 \\
\hline SWP-3 & $-0,009$ & $-0,005$ & 0,016 & 0,02 & 0,006 \\
\hline Total & 0,209 & 0,209 & 0,352 & 0,359 & 0,282 \\
\hline
\end{tabular}

Tabel 3

Indeks Entropy Theil Between Dan Theil Within Sektor Pertanian Kabupaten Semarang Tahun 2008-2011

\begin{tabular}{|c|c|c|c|c|c|c|c|c|c|c|c|c|}
\hline \multirow[t]{3}{*}{ SWP } & \multicolumn{12}{|c|}{ Indeks Entropy Theil Sektor Pertanian } \\
\hline & \multicolumn{3}{|c|}{2008} & \multicolumn{3}{|c|}{2009} & \multicolumn{3}{|c|}{2010} & \multicolumn{3}{|c|}{2011} \\
\hline & $\begin{array}{c}\text { Theil } \\
\text { Between }\end{array}$ & $\begin{array}{c}\text { Theil } \\
\text { Within }\end{array}$ & $\begin{array}{l}\text { Total } \\
\text { Theil }\end{array}$ & $\begin{array}{c}\text { Theil } \\
\text { Between }\end{array}$ & $\begin{array}{l}\text { Theil } \\
\text { Within }\end{array}$ & $\begin{array}{l}\text { Total } \\
\text { Theil }\end{array}$ & $\begin{array}{c}\text { Theil } \\
\text { Between }\end{array}$ & $\begin{array}{c}\text { Theil } \\
\text { Within }\end{array}$ & $\begin{array}{l}\text { Total } \\
\text { Theil }\end{array}$ & $\begin{array}{c}\text { Theil } \\
\text { Between }\end{array}$ & $\begin{array}{c}\text { Theil } \\
\text { Within }\end{array}$ & $\begin{array}{l}\text { Total } \\
\text { Theil }\end{array}$ \\
\hline SWP-1 & 0,06 & 0,068 & 0,128 & 0,056 & 0,068 & 0,123 & 0,074 & 0,134 & 0,208 & 0,071 & 0,137 & 0,209 \\
\hline SWP-2 & 0,018 & 0,072 & 0,091 & 0,017 & 0,073 & 0,09 & 0,008 & 0,12 & 0,128 & 0,007 & 0,123 & 0,13 \\
\hline SWP-3 & $-0,051$ & 0,042 & $-0,009$ & $-0,049$ & 0,045 & $-0,005$ & $-0,051$ & 0,066 & 0,016 & $-0,05$ & 0,07 & 0,02 \\
\hline Total & 0,026 & 0,183 & 0,209 & 0,023 & 0,185 & 0,209 & 0,031 & 0,321 & 0,352 & 0,029 & 0,33 & 0,359 \\
\hline
\end{tabular}

Sumber : BPS Kab. Semarang, Kabupaten Dalam Angka, Kecamatan Dalam Angka, dan PDRB Kecamatan 2009-2012 (diolah) 
Pemilihan dan Pengujian Reliabilitas Model Regresi

Pemilihan Model Regresi

Berdasarkan estimasi persamaan regresi pada Eviews 7.2 dapat diperoleh 3 Model Panel Least Square (PLS)

Dependent Variable: INDEKSET

Method: Panel Least Squares

Sample: 20082011

Periods included: 4

Cross-sections included: 19

Total panel (balanced) observations: 76

\begin{tabular}{lrcrr}
\hline \hline \multicolumn{1}{c}{ Variable } & Coefficient & Std. Error & t-Statistic & Prob. \\
\hline \multicolumn{1}{c}{ C } & 0.028672 & 0.007036 & 4.074919 & 0.0001 \\
\multicolumn{1}{c}{ LAHAN } & $7.80 \mathrm{E}-07$ & $2.57 \mathrm{E}-06$ & 0.303935 & 0.7620 \\
\multicolumn{1}{c}{ NAKER } & $-2.35 \mathrm{E}-06$ & $4.95 \mathrm{E}-07$ & -4.739706 & 0.0000 \\
\hline \hline R-squared & 0.328927 & Mean dependent var & 0.004797 \\
Adjusted R-squared & 0.310542 & S.D. dependent var & 0.019645 \\
S.E. of regression & 0.016312 & Akaike info criterion & -5.355186 \\
Sum squared resid & 0.019423 & Schwarz criterion & -5.263183 \\
Log likelihood & 206.4971 & Hannan-Quinn criter. & -5.318417 \\
F-statistic & 17.89054 & Durbin-Watson stat & 0.823392 \\
Prob(F-statistic) & 0.000000 & & \\
\hline \hline
\end{tabular}

\section{Model Fixed Effects (FEM)}

Dependent Variable: INDEKSET

Method: Panel Least Squares

Sample: 20082011

Periods included: 4

Cross-sections included: 19

Total panel (balanced) observations: 76

\begin{tabular}{lrrrr}
\hline \hline \multicolumn{1}{c}{ Variable } & Coefficient & Std. Error & t-Statistic & Prob. \\
\hline \hline \multicolumn{1}{c}{ C } & -0.018400 & 0.015796 & -1.164879 & 0.2491 \\
NAKAN & $1.01 \mathrm{E}-05$ & $4.47 \mathrm{E}-06$ & 2.263343 & 0.0276 \\
& $-1.06 \mathrm{E}-06$ & $5.45 \mathrm{E}-07$ & -1.940190 & 0.0575 \\
\hline \hline & Effects Specification & & \\
\hline \hline & & & \\
Cross-section fixed (dummy variables) & & & \\
\hline \hline & & & \\
R-squared & 0.741427 & Mean dependent var & 0.004797 \\
Adjusted R-squared & 0.647401 & S.D. dependent var & -5.835202 \\
S.E. of regression & 0.011665 & Akaike info criterion & -5.191183 \\
Sum squared resid & 0.007484 & Schwarz criterion & -5.577821 \\
Log likelihood & 242.7377 & Hannan-Quinn criter. & 2.065076 \\
F-statistic & 7.885306 & Durbin-Watson stat & \\
Prob(F-statistic) & 0.000000 & & \\
\hline \hline
\end{tabular}


Cross-section Fixed Effects :

\begin{tabular}{ccc}
\hline & KECAMATAN & Effect \\
\hline 1 & Getasan & -0.013586 \\
\hline 2 & Tengaran & -0.003841 \\
\hline 3 & Susukan & -0.007842 \\
\hline 4 & Kaliwungu & 0.013231 \\
\hline 5 & Suruh & -0.021714 \\
\hline 6 & Pabelan & 0.001698 \\
\hline 7 & Tuntang & -0.011916 \\
\hline 8 & Banyubiru & -0.017925 \\
\hline 9 & Jambu & -0.021132 \\
\hline 10 & Sumowono & -0.015566 \\
\hline 11 & Ambarawa & 0.041383 \\
\hline 12 & Bandungan & -0.007408 \\
\hline 13 & Bawen & 0.009529 \\
\hline 14 & Bringin & -0.016938 \\
\hline 15 & Bancak & 0.006497 \\
\hline 16 & Pringapus & -0.002703 \\
\hline 17 & Bergas & 0.024079 \\
\hline 18 & Ungaran Barat & 0.043241 \\
\hline 19 & Unqaran Timur & 0.000912 \\
\hline
\end{tabular}

\section{Model Random Effects (REM)}

Dependent Variable: INDEKSET

Method: Panel EGLS (Cross-section random effects)

Sample: 20082011

Periods included: 4

Cross-sections included: 19

Total panel (balanced) observations: 76

Swamy and Arora estimator of component variances

\begin{tabular}{|c|c|c|c|c|}
\hline Variable & Coefficient & Std. Error & t-Statistic & Prob. \\
\hline C & 0.017653 & 0.009362 & 1.885558 & 0.0633 \\
\hline LAHAN & 1.97E-06 & 2.89E-06 & 0.682024 & 0.4974 \\
\hline NAKER & $-1.74 \mathrm{E}-06$ & $4.72 \mathrm{E}-07$ & -3.688524 & 0.0004 \\
\hline \multicolumn{5}{|c|}{ Effects Specification } \\
\hline & & & S.D. & Rho \\
\hline Cross-section random & & & 0.011002 & 0.4708 \\
\hline Idiosyncratic random & & & 0.011665 & 0.5292 \\
\hline \multicolumn{5}{|c|}{ Weighted Statistics } \\
\hline R-squared & 0.156470 & \multirow{5}{*}{\multicolumn{2}{|c|}{$\begin{array}{l}\text { Mean dependent var } \\
\text { S.D. dependent var } \\
\text { Sum squared resid } \\
\text { Durbin-Watson stat }\end{array}$}} & 0.002247 \\
\hline Adjusted R-squared & 0.133360 & & & 0.013167 \\
\hline S.E. of regression & 0.012258 & & & 0.010969 \\
\hline F-statistic & 6.770551 & & & 1.371487 \\
\hline Prob(F-statistic) & 0.002008 & & & \\
\hline \multicolumn{5}{|c|}{ Unweighted Statistics } \\
\hline R-squared & 0.289795 & \multirow{2}{*}{\multicolumn{2}{|c|}{$\begin{array}{l}\text { Mean dependent var } \\
\text { Durbin-Watson stat }\end{array}$}} & 0.004797 \\
\hline Sum squared resid & 0.020556 & & & 0.731829 \\
\hline
\end{tabular}




\begin{tabular}{clc}
\multicolumn{3}{c}{ Cross-section Random Effects: } \\
\hline & KECAMATAN & Effect \\
\hline 1 & Getasan & 0.008410 \\
\hline 2 & Tengaran & -0.004234 \\
\hline 3 & Susukan & -0.004819 \\
\hline 4 & Kaliwungu & 0.001234 \\
\hline 5 & Suruh & -0.005172 \\
\hline 6 & Pabelan & 0.002026 \\
\hline 7 & Tuntang & -0.008494 \\
\hline 8 & Banyubiru & -0.009685 \\
\hline 9 & Jambu & -0.009938 \\
\hline 10 & Sumowono & -0.004310 \\
\hline 11 & Ambarawa & 0.020943 \\
\hline 12 & Bandungan & -0.005000 \\
\hline 13 & Bawen & 0.001880 \\
\hline 14 & Bringin & -0.008077 \\
\hline 15 & Bancak & -0.000958 \\
\hline 16 & Pringapus & -0.006821 \\
\hline 17 & Bergas & 0.015926 \\
\hline 18 & Ungaran Barat & 0.023775 \\
\hline 19 & Ungaran Timur & -0.006688 \\
\hline
\end{tabular}

Untuk menentukan model regresi yang paling tepat dari ketiga pilihan model regresi di atas, maka terlebih dahulu harus dilakukan Uji (F) dan Chi-Kuadrat serta uji Hausman yang hasilnya dapat dilihat pada tabel 4 dan tabel 5.

Tabel 4

Berdasarkan tabel diatas dapat dilihat bahwa nilai probabilitas test crosssection random effects pada Uji Hausman menghasilkan angka bernilai 0,00082 yang berarti sangat signifikan pada tingkat signifikansi 95\% ( $\alpha=5 \%)$. Sehingga kepu-

Hasil Uji (F) Dan Chi-Kuadrat Dengan Likelihood Ratio Test

\begin{tabular}{|c|c|c|c|}
\hline Effects Test & Statistic & d.f. & Prob. \\
\hline $\begin{array}{l}\text { Cross-section F } \\
\text { Cross-section Chi-square }\end{array}$ & $\begin{array}{r}4.874514 \\
72.481229\end{array}$ & $\begin{array}{r}(18,55) \\
18\end{array}$ & $\begin{array}{l}0.0000 \\
0.0000\end{array}$ \\
\hline $\begin{array}{l}\text { Hipotesis Pengujian : } \\
\mathrm{H}_{0} \text { : model mengikuti Pooled Least } \\
\text { Square (PLS). } \\
\mathrm{H}_{\mathrm{a}} \text { : model mengikuti Fixed Effects } \\
\text { Model (FEM). }\end{array}$ & \multicolumn{3}{|c|}{$\begin{array}{l}\text { Kriteria Pengujian berdasarkan } \\
\text { hipotesis : } \\
\mathrm{H}_{0} \text { ditolak jika nilai probabilitas ( } p \text {-value } \\
<5 \% \text { ) } \\
\mathrm{H}_{0} \text { diterima jika nilai probabilitas ( } p \text { - } \\
\text { value }>5 \% \text { ) }\end{array}$} \\
\hline
\end{tabular}

Berdasarkan hasil Likelihood ratio test sebagaimana pada tabel 4 dapat diketahui bahwa baik uji (F) maupun Chi-Kuadrat bernilai signifikan dikarenakan nilai probabilitas $(p$-value $)=0,0000$ lebih kecil dari $\alpha=5 \%$. Dengan demikian HO ditolak dan Ha diterima sehingga model mengikuti Fixed Effects Model (FEM). tusan yang diambil pada pengujian Hausman ini adalah menolak $\mathrm{HO}(p$-value $<0,5)$ dan menerima $\mathrm{Ha}$ atau mengikuti model Fixed Effects (FEM). 
Tabel 5

Hasil Uji Hausman Dengan Test Cross-Section Random Effects Test cross-section random effects

\begin{tabular}{|c|c|c|c|}
\hline Test Summary & $\begin{array}{l}\text { Chi-Sq. } \\
\text { Statistic }\end{array}$ & Chi-Sq. d.f. & Prob. \\
\hline Cross-section random & 9.608701 & 2 & 0.0082 \\
\hline $\begin{array}{l}\text { Hipotesis Pengujian: } \\
\mathrm{H}_{0} \text { : model mengikuti Random Effects } \\
\text { Model (REM). } \\
\mathrm{H}_{\mathrm{a}} \text { : model mengikuti Fixed Effects } \\
\text { Model (FEM). }\end{array}$ & \multicolumn{3}{|c|}{$\begin{array}{l}\text { Kriteria Pengujian berdasarkan } \\
\text { hipotesis : } \\
H_{0} \text { ditolak jika nilai probabilitas ( } p \text { - } \\
\text { value) }<a=5 \% \text { ) } \\
H_{0} \text { diterima jika nilai probabilitas ( } p \text { - } \\
\text { value) }>a=5 \% \text { ) }\end{array}$} \\
\hline
\end{tabular}

Pengujian Kesesuaian Model Regresi (Goodness of Fit Test)

Hasil pemilihan model regresi menunjukkan bahwa model Fixed Effects (FEM) merupakan model regresi yang paling tepat sesuai dengan karakteristik data penelitian, sehingga pada tahap selanjutnya model Fixed Effects (FEM) ini dapat digunakan untuk menganalisis pokok permasalahan penelitian.

Untuk mengetahui realibilitas model Fixed Effects (FEM) tersebut maka harus dilakukan analisis model regresi dengan tujuan untuk mengetahui ketepatan model regresi dalam mengestimasi nilai aktualnya. Pada analisis ini akan dilakukan serangkaian uji kesesuaian (goodness of fit test) model regresi yang diukur melalui nilai statistik $(F)$, nilai statistik $(t)$, dan koefisien determinasi dari model persamaan regresi.
Agar mempermudah dalam melakukan analisis, maka parameter parameter untuk melakukan goodness of fit test dapat disederhanakan ke dalam bentuk tabel 6.

Melalui parameter goodness of fit test dari model Fixed Effects Model (FEM) yang rangkumannya disajikan sebagaimana pada tabel 11 dapat diketahui bahwa koefisien variabel Lahan $\left(X_{1}\right)$ bernilai positif sementara koefisien variabel Naker $\left(X_{2}\right)$ bernilai negatif. Dengan mengacu kepada karakteristik koefisien tersebut dapat disimpulkan bahwa variabel Lahan $\left(\mathrm{X}_{1}\right)$ berpengaruh positif tehadap indeks Entropy Theil $(\mathrm{Y})$ sedangkan variabel Naker $\left(\mathrm{X}_{2}\right)$ berpengaruh negatif terhadap indeks Entropy Theil (Y).

Tabel 6

Parameter Goodness Of Fit Test Berdasarkan Model Fixed Effects (Fem)

\begin{tabular}{lcccl}
\hline \multicolumn{1}{c}{ Variabel } & Koefisien & t Hitung & Prob. & \multicolumn{1}{c}{ Pengaruh } \\
\hline Lahan $\left(\mathrm{X}_{1}\right)$ & $1.01 \mathrm{E}-05$ & 2.263343 & 0.0276 & Positif dan signifikan \\
\hline Naker $\left(\mathrm{X}_{2}\right)$ & $-1.06 \mathrm{E}-06$ & -1.940190 & 0.0575 & Negatif dan tidak signifikan \\
\hline Konstanta & $=-0.018400$ & F Hitung & $=7.8853206$ & $\mathrm{t}_{\text {Tabel }}=0.67787^{*}$ \\
$\mathrm{R}^{2}$ & $=0.741427$ & F Prob. & $=0.0000000$ & $\mathrm{~F}_{\text {Tabel }}=3.12^{*}$ \\
$\begin{array}{l}\text { S.E of } \\
\text { regression }\end{array}$ & $=0.011665$ & & & \\
\hline
\end{tabular}

${ }^{*}$ Catatan : Berdasarkan nilai rujukan dua arah untuk $\alpha=5 \%$

Sumber : Data penelitian yang diolah 
Berdasarkan hasil uji statistik $(F)$, diperoleh nilai $F_{\text {hitung }}(7,8853206)>F_{\text {tabel }}$ $(3,12)$ yang signifikan pada $\alpha=5 \%$, sehingga variabel Lahan $\left(\mathrm{X}_{1}\right)$ dan Naker $\left(\mathrm{X}_{2}\right)$ secara bersama-sama berpengaruh terhadap indeks Entropy Theil. Dalam pengujian secara parsial, uji statistik (t) menunjukkan variabel Lahan $\left(\mathrm{X}_{1}\right)$ berpengaruh signifikan terhadap indeks Entropy Theil (Y) pada a $=5 \%$. Namun demikian uji statistik (t) untuk variabel Naker $\left(\mathrm{X}_{2}\right)$ justru menunjukkan pengaruh yang tidak signifikan terhadap indeks Entropy Theil.

Dengan demikian, melalui serangkaian hasil pengujian di atas dapat disimpulkan bahwa selama periode tahun 2008-2011 luas lahan pertanian berpengaruh positif dan signifikan menimbulkan terjadinya ketimpangan antar wilayah pada sektor pertanian di Kabupaten Semarang. Adapun selama periode tahun 20082011 jumlah tenaga kerja berpengaruh negatif dan tidak signifikan menimbulkan terjadinya ketimpangan antar wilayah pada sektor pertanian di Kabupaten Semarang.

Untuk mengukur kemampuan model regresi data panel dalam menerangkan variasi variabel dependen digunakan analisis koefisien determinasi $\left(\mathrm{R}^{2}\right)$. Berdasarkan parameter goodness of fit test dari model Fixed Effects Model (FEM) yang disajikan pada tabel 11 dapat diketahui nilai R2 sebesar 0,741427 menunjukkan $74,14 \%$ variasi dari indeks Entropy Theil dapat dijelaskan oleh variasi dari dua variabel independen yaitu Lahan dan Naker, sedangkan sisanya $25,85 \%$ dari variasi perubahan indeks Entropy Theil yang terjadi selama periode penelitian dijelaskan oleh variasi variabel lain di luar model regresi. Dengan demikian dapat disimpulkan bahwa selama periode tahun 2008-2011 luas lahan pertanian dan jumlah tenaga kerja sektor pertanian dipercaya mampu menjelaskan terjadinya ketimpangan antar wilayah pada sektor pertanian di Kabupaten Semarang dengan tingkat akurasi sebesar $74,14 \%$.

\section{Pengujian Asumsi Klasik Model Regresi Uji Multikolinearitas}

Perhitungan pada Eviews 7.2 menghasilkan nilai koefisien korelasi antar variabel bebas model regresi pada tabel 7 .

Berdasarkan hasil perhitungan di atas dapat diketahui koefisien korelasi antara variabel bebas lahan pertanian dan variabel tenaga kerja sektor pertanian adalah sebesar 0,649521 yang nilainya lebih kecil dari 0,8 $(0,649521<0,8)$. Dengan demikian $\mathrm{H}_{0}$ diterima dan $\mathrm{H}_{a}$ ditolak sehingga dapat disimpulkan bahwa model regresi yang digunakan terbebas atau tidak mengalami masalah multikolinearitas.

Tabel 7

\section{Perhitungan Nilai Koefisien Korelasi Antar Variabel Bebas}

\begin{tabular}{|c|c|}
\hline Lahan & Naker \\
\hline 1.000000 & 0.649521 \\
\hline 0.649521 & 1.000000 \\
\hline
\end{tabular}

Hipotesis Pengujian:

$\mathrm{H}_{0}$ : model tidak mengalami masalah multikolinearitas.

$\mathrm{H}_{\mathrm{a}}$ : model mengalami masalah multikolinearitas.

Kriteria Pengujian berdasarkan hipotesis :

$\mathrm{H}_{0}$ ditolak jika nilai koefisien korelasi $>0,8$.

$\mathrm{H}_{0}$ diterima jika nilai koefisien korelasi $<0,8$. 


\section{Uji Heteroskedastisitas}

Salah satu cara untuk mendeteksi adanya masalah heteroskedastisitas dalam model regresi dapat dilakukan melalui uji Breusch-Pagan-Godfrey dengan hipotesis : $\mathrm{H}_{0}=$ model bersifat homoskedastis (tidak mengalami masalah heteroskedastisitas) sedangkan $\mathrm{Ha}_{\mathrm{a}}=$ model mengalami masalah heteroskedastisitas. Selain itu kriteria Pengujian berdasarkan hipotesis $\mathrm{H}_{0}$ diterima jika nilai $X^{2}$ hitung $<X^{2}$ tabel dan $\mathrm{H}_{0}$ ditolak jika nilai $X^{2 \text { hitung }}>X^{2}$ tabel.

Melalui uji Breusch-Pagan-Godfrey pada taraf signifikansi $\alpha=5 \%$ dan derajat kebebasan (df) $=2$ dapat diperoleh nilai $X^{2}$ tabel sebesar $=5,99146$. Dengan demikian dapat disimpulkan bahwa nilai $X^{2}$ hitung < $X^{2}$ tabel $(0,00000653<5,99146)$, sehingga $\mathrm{H}_{0}$ diterima dan $\mathrm{H}_{a}$ ditolak. Atau dengan kata lain dapat dinyatakan bahwa data bersifat homoskedastis atau bebas dari masalah heteroskedastisitas.

\section{Uji Autokorelasi}

Salah satu cara untuk mendeteksi adanya masalah autokorelasi dalam model regresi dapat dilakukan melalui uji Durbin Watson (DW test) dua arah yang mengikuti hipotesis sebagai berikut:

$\mathrm{H}_{0}$ : model tidak mengalami masalah autokorelasi positif dan negatif.

$\mathrm{Ha}$ : model mengalami masalah autokorelasi.

Kriteria pengujian berdasarkan hipotesis: jumlah variabel bebas $(k)=2$, maka dapat diperoleh parameter-parameter sebagai dasar dalam menentukan batas-batas letak Dwstatistic untuk pengujian Durbin Watson sebagai berikut :

$$
\begin{gathered}
d U=1,6819 \\
4-d U=2,3181 .
\end{gathered}
$$

Dengan demikian dapat disimpulkan bahwa nilai Durbin Watson statistic terletak diantara dU dan 4 - dU $(1,6819<$ $2,065076<2,3181$ ) sehingga $\mathrm{H}_{0}$ diterima dan $\mathrm{H}_{\mathrm{a}}$ ditolak. Atau dengan kata lain dapat dinyatakan bahwa data tidak mengalami atau bebas dari masalah autokorelasi.

\section{Interpretasi Model Regresi}

Berdasarkan parameter yang dihasilkan dari pemodelan regresi Fixed Effects (FEM) dapat diperoleh persamaan regresi sebagai berikut :

Indekset $=-0,018400+1,01 \mathrm{E}-05$ Lahan -1.06E-06 Naker

Apabila nilai eksponensial (perpangkatan) pada persamaan regresi di atas dikonversi ke bentuk desimal murni maka bentuk persamaannya akan berubah menjadi :

Indekset $=-0,0184+0,0000101$ Lahan 0,00000106 Naker

Berdasarkan persamaan regresi di atas nilai konstanta sebesar $-0,0184$, hal itu berarti apabila variabel luas lahan pertanian dan jumlah tenaga kerja sektor pertanian bernilai 0 (nol), maka indeks Entropy Theil (indeks ketimpangan wilayah) akan berni-

\begin{tabular}{|l|c|c|c|c|}
\hline $\begin{array}{c}\text { Tolak } \mathrm{H}_{0}: \\
\text { ada } \\
\begin{array}{c}\text { autokorelasi } \\
\text { positif }\end{array}\end{array}$ & $\begin{array}{c}\text { Tidak dapat } \\
\text { diputuskan }\end{array}$ & $\begin{array}{c}\text { Menerima } \mathrm{H}_{0}: \\
\text { tidak ada } \\
\text { autokorelasi } \\
0\end{array}$ & $\begin{array}{c}\text { Tidak dapat } \\
\text { diputuskan }\end{array}$ & $\begin{array}{c}\text { Tolak } \mathrm{H}_{0}: \text { ada } \\
\text { autokorelasi } \\
\text { negatif }\end{array}$ \\
\hline
\end{tabular}

Adapun nilai $D w$ statistic dapat diidentifikasi melalui nilai Durbin-Watson stat yang termuat dalam summary hasil estimasi model regresi dengan metode fixed effects yaitu sebesar $=2,065076$.

Dengan melakukan pengujian menggunakan tingkat signifikansi $\alpha=5 \%$ untuk jumlah data observasi $(n)=76$ dan

lai sebesar $-0,0184$. Selain itu nilai koefisien regresi variabel luas lahan pertanian sebesar 0,0000101 berarti apabila luas lahan pertanian bertambah sebanyak 1 hektar, maka nilai indeks Entropy Theil (indeks ketimpangan wilayah) akan mengalami peningkatan sebesar 0,0000101 satuan dengan asumsi variabel bebas 
lainnya (jumlah tenaga kerja sektor pertanian) bernilai tetap. Nilai koefisien regresi variabel jumlah tenaga kerja sektor pertanian sebesar $-0,00000106$ berarti apabila jumlah tenaga kerja sektor pertanian bertambah sebanyak 1 jiwa (orang), maka nilai indeks Entropy Theil (indeks ketimpangan wilayah) akan mengalami penurunan sebesar 0,00000106 satuan dengan asumsi variabel bebas lainnya (luas lahan pertanian) bernilai tetap.

\section{Analisis Hasil Penelitian}

Karakteristik Umum Ketimpangan Antar Wilayah pada Sektor Pertanian di Kabupaten Semarang Tahun 2008-2011

Melalui hasil interpretasi model regresi dapat diketahui bahwa saat variabel luas lahan pertanian dan jumlah tenaga kerja sektor pertanian bernilai $=0$, maka ketimpangan wilayah pada sektor pertanian di Kabupaten Semarang berkurang sebesar $(-0,0184)$. Dengan demikian, tingkat ketimpangan wilayah pada sektor pertanian di Kabupaten Semarang akan menunjukkan kecenderungan menurun walaupun tidak mendapat pengaruh dari variabel apapun.

Jika ditinjau dari sudut pandang pemerataan, kondisi tersebut dinilai baik karena dengan berkurangnya ketimpangan berarti tingkat kesejahteraan pekerja sektor pertanian diharapkan akan semakin merata di setiap wilayah. Namun, setelah ditelaah lebih lanjut ternyata kecenderungan menurunnya ketimpangan tanpa dipengaruhi oleh variabel apapun tersebut menunjukkan masih rendahnya kinerja ekonomi sektor pertanian.

Data BPS menunjukkan bahwasanya selama periode 2008-2011 kontribusi sektor pertanian terhadap pembentukan PDRB relatif tidak mengalami pertumbuhan signifikan dan bahkan cenderung menurun kontribusinya. Fenomena/ gejala ini dapat dilihat dari proporsi sektor pertanian terhadap kontribusi pembentukan PDRB ADHK di Kabupaten Semarang (sebagaimana pada tabel 6) yang hanya mengalami kenaikan dari tahun 2008 ke tahun 2009 namun selanjutnya mengalami penurunan dari tahun 2009 ke tahun 2010 dan dari tahun 2010 ke tahun 2011.

Kecenderungan penurunan kontribusi sektor pertanian terhadap pembentukan PDRB yang terjadi di Kabupaten Semarang tentunya sejalan dengan gejala penurunan kinerja ekonomi sektor pertanian di negara-negara berkembang sebagaimana yang diutarakan oleh Todaro dan Smith (2006:505) dan teori ekonomi pembangunan modern umumnya yang menyatakan bahwa semakin berkembang suatu negara, maka kontribusi sektor pertanian terhadap pembentukan PNB akan semakin kecil, sedangkan kontribusi sek-

Tabel 8

Kontribusi Sektor Pertanian Terhadap Pembentukan Pdrb Adhk* Kabupaten Semarang Tahun 2008-2011

\begin{tabular}{cccc}
\hline Tahun & $\begin{array}{c}\text { PDRB Sektor } \\
\text { Pertanian (Juta } \\
\text { Rp.) }\end{array}$ & $\begin{array}{c}\text { TotalPDRB } \\
\text { Sektoral (Juta } \\
\text { Rp.) }\end{array}$ & $\begin{array}{c}\text { Kontribusi Sektor } \\
\text { PertanianTerhadap PDRB } \\
\text { (\%) }\end{array}$ \\
\hline 2008 & $659.841,30$ & $5.079 .003,70$ & 12,99 \\
\hline 2009 & $693.711,30$ & $5.300 .723,40$ & 13,09 \\
\hline 2010 & $709.056,60$ & $5.560 .551,90$ & 12,75 \\
\hline 2011 & $738.896,40$ & $5.877 .190,90$ & 12,57 \\
\hline Rata-rata & $700.376,40$ & $\mathbf{5 . 4 5 4 . 3 6 7 , 4 8}$ & $\mathbf{1 2 , 8 5}$ \\
\hline *Atas Dasar Harga Konstan Tahun 2000 & &
\end{tabular}

Sumber : BPS Kab. Semarang, PDRB Sektoral Tahun 2012 
tor industri dan perdagangan justru semakin besar.

Dengan demikian, terjadinya penurunan kontribusi sektor pertanian terhadap pembentukan PDRB di Kabupaten Semarang dapat dijelaskan sebagai efek yang diakibatkan oleh terjadinya transformasi struktural dalam perekonomian suatu negara (khususnya di negara berkembang), yang ditandai dengan pergeseran sektor ekonomi utama dari sektor pertanian ke sektor industri (manufaktur) dan sektor perdagangan. Sehingga di saat sektor industri manufaktur dan sektor perdagangan terus mengalami pertumbuhan, sektor pertanian justru mengalami stagnasi sehingga andil output sektor pertanian dalam PDRB secara keseluruhan terus menurun.

Terjadinya proses transformasi struktural dalam perekonomian di Kabupaten Semarang dapat terlihat dari laju pertumbuhan ekonomi rata-rata sektor pertanian yang nilainya lebih kecil jika dibandingkan dengan sektor industri dan sektor perdagangan sebagaimana nampak pada tabel 9.

Adapun secara mikro, penggunaan metode fixed effects sebagai instrumen dalam memodelkan ketimpangan wilayah sektor pertanian di Kabupaten Semarang menghasilkan nilai intersep (konstanta) yang berbeda untuk tiap-tiap kecamatan. Nilai intersep tersebut merepresentasikan karakteristik ketimpangan wilayah yang berbeda-beda di masing-masing kecamatan pada saat sama sekali tidak ada pengaruh dari variabel lahan pertanian dan jumlah tenaga kerja pertanian.
Tanda minus (-) pada nilai intersep menunjukkan kecamatan tersebut berpotensi negatif menimbulkan ketimpangan atau memiliki karakteristik yang cenderung mengurangi terjadinya ketimpangan wilayah. Sedangkan nilai intersep yang positif menunjukkan kecamatan berpotensi positif menimbulkan ketimpangan atau dengan kata lain memiliki karakteristik cenderung menambah ketimpangan wilayah.

Berdasarkan tabel 10, dapat diidentifikasi dari total 19 kecamatan, terdapat 8 (delapan) diantaranya berpotensi positif menimbulkan ketimpangan atau memiliki karakteristik cenderung menambah ketimpangan wilayah, yaitu terdiri Kecamatan Bergas, Kecamatan Ungaran Barat dan Kecamatan Ungaran Timur yang masuk dalam SWP-1, Kecamatan Ambarawa dan Kecamatan Bawen yang masuk dalam SWP-2, serta Kecamatan Bancak, Kecamatan Kaliwungu dan Kecamatan Pabelan yang masuk dalam SWP-3. Sedangkan sisanya sebanyak 11 (sebelas) kecamatan berpotensi negatif menimbulkan ketimpangan atau memiliki karakteristik yang cenderung mengurangi terjadinya ketimpangan wilayah.

Dengan demikian dapat diketahui bahwa potensi positif atau karakteristik untuk cenderung menimbulkan ketimpangan dimiliki oleh seluruh SWP. Potensi penyebab ketimpangan tertinggi terdapat di SWP-1 dikarenakan memiliki kecamatan dengan total nilai intersep yang lebih besar jika dibandingkan dengan SWP-SWP lainnya. Potensi penyebab ketimpangan kedua tertinggi dimilki oleh SWP-2, sedangkan potensi penyebab ketimpangan terendah adalah pada SWP-3.

Tabel 9

Laju Pertumbuhan 3 Sektor Ekonomi Utama Di Kabupaten Semarang Tahun 2008 $-2011$

\begin{tabular}{cccccc}
\hline Sektor & $\mathbf{2 0 0 8}$ & $\mathbf{2 0 0 9}$ & $\mathbf{2 0 1 0}$ & $\mathbf{2 0 1 1}$ & Rata-Rata \\
\hline Pertanian & - & $5,13 \%$ & $2,21 \%$ & $4,21 \%$ & $3,85 \%$ \\
\hline Industri & - & $3,88 \%$ & $4,80 \%$ & $5,54 \%$ & $4,74 \%$ \\
\hline Perdagangan & - & $3,95 \%$ & $5,86 \%$ & $5,32 \%$ & $\mathbf{5 , 0 4 \%}$ \\
\hline
\end{tabular}

Sumber : BPS Kab. Semarang, PDRB Sektoral Tahun 2012 
Tabel 10

Nilai Intersep (Konstanta) Tiap Kecamatan Berdasarkan Regresi Model Fixed Effects (Fem)

\begin{tabular}{lllc}
\hline No. & \multicolumn{1}{c}{ Kecamatan } & SWP & $\begin{array}{c}\text { Nilai } \\
\text { (Kontersep }\end{array}$ \\
\hline 1. & Bergas & SWP-1 & 0.024079 \\
\hline 2. & Pringapus & SWP-1 & -0.002703 \\
\hline 3. & Ungaran Barat & SWP-1 & 0.043241 \\
\hline 4. & Ungaran Timur & SWP-1 & 0.000912 \\
\hline 5. & Ambarawa & SWP-2 & 0.041383 \\
\hline 6. & Bandungan & SWP-2 & -0.007408 \\
\hline 7. & Banyubiru & SWP-2 & -0.017925 \\
\hline 8. & Bawen & SWP-2 & 0.009529 \\
\hline 9. & Jambu & SWP-2 & -0.021132 \\
\hline 10. & Sumowono & SWP-2 & -0.015566 \\
\hline 11. & Tuntang & SWP-2 & -0.011916 \\
\hline 12. & Bancak & SWP-3 & 0.006497 \\
\hline 13. & Bringin & SWP-3 & -0.016938 \\
\hline 14. & Getasan & SWP-3 & -0.013586 \\
\hline 15. & Kaliwungu & SWP-3 & 0.013231 \\
\hline 16. & Pabelan & SWP-3 & 0.001698 \\
\hline 17. & Suruh & SWP-3 & -0.021714 \\
\hline 18. & Susukan & SWP-3 & -0.007842 \\
\hline 19. & Tengaran & SWP-3 & -0.003841 \\
\hline & & & \\
\hline
\end{tabular}

Adapun dari 10 (sepuluh) kecamatan yang telah ditetapkan sebagai kawasan agropolitan, hanya 3 (tiga) diantaranya yang berpotensi positif atau memiliki karakteristik menambah ketimpangan wilayah pada sektor pertanian; yaitu Kecamatan Bancak, Kecamatan Kaliwungu, dan Kecamatan Pabelan.

Karakteristik Pengaruh Luas Lahan Pertanian Terhadap Ketimpangan Antar Wilayah pada Sektor Pertanian di Kabupaten Semarang Tahun 2008-2011

Untuk membantu menjelaskan secara lebih mendalam mengenai pengaruh perbedaan luas lahan pertanian terhadap ketimpangan antar wilayah pada sektor pertanian di Kabupaten Semarang dalam kurun waktu 2008-2011, maka dapat dilakukan analisis silang (kontijensi) yang membandingkan antara laju perubahan luas lahan pertanian dengan perubahan nilai indeks ketimpangan wilayah sektor pertanian per kecamatan sebagaimana pada tabel 11.
Analisis kontijensi berdasarkan tabel 11 menunjukkan bahwa hubungan laju perubahan luas lahan pertanian dengan perubahan nilai indeks ketimpangan wilayah per kecamatan secara mayoritas adalah bersifat searah/positif. Dimana dari 57 (lima puluh tujuh) pasang data yang diperbandingkan, 32 (tiga puluh dua) diantaranya $(56,14 \%)$ menunjukkan kecocokan pola dalam sifat/arah hubungan.

Sebagaimana terlihat pada tabel 11, di tahun 2009 sifat hubungan positif antara laju perubahan luas lahan dengan perubahan nilai indeks ketimpangan wilayah berlaku di 8 kecamatan. Selanjutnya di tahun 2010 hubungan tersebut naik menjadi berlaku di 14 kecamatan, dan di tahun 2011 turun menjadi 10 kecamatan.

Dari seluruh kecamatan, hanya terdapat 3 (tiga) diantaranya yang yang menunjukkan adanya konsistensi hubungan positif antara laju perubahan luas lahan dengan perubahan nilai indeks ketimpangan wilayah dari tahun ke tahun, yaitu Kecamatan Pabelan, Kecamatan 
Tabel 11

Perbandingan Laju Perubahan Luas Lahan Pertanian Dan Perubahan Nilai Indeks Ketimpangan Wilayah (Entropy Theil) Sektor Pertanian Berdasarkan Kecamatan Di Kabupaten Semarang Tahun 2008-2011

\begin{tabular}{|c|c|c|c|c|c|c|c|c|c|c|}
\hline \multirow[b]{2}{*}{ No } & \multirow[b]{2}{*}{ Kecamatan } & \multirow[b]{2}{*}{ SWP } & \multicolumn{2}{|c|}{2008} & \multicolumn{2}{|c|}{2009} & \multicolumn{2}{|c|}{2010} & \multicolumn{2}{|c|}{2011} \\
\hline & & & $\begin{array}{c}\text { Laju } \\
\text { Perub. } \\
\text { Luas } \\
\text { Lahan } \\
\text { Pertanian }\end{array}$ & $\begin{array}{l}\text { Perub. } \\
\text { Indeks } \\
\text { Entropy } \\
\text { Theil }\end{array}$ & $\begin{array}{c}\text { Laju } \\
\text { Perub. } \\
\text { Luas } \\
\text { Lahan } \\
\text { Pertani } \\
\text { an }\end{array}$ & $\begin{array}{l}\text { Perub. } \\
\text { Indeks } \\
\text { Entropy } \\
\text { Theil }\end{array}$ & $\begin{array}{c}\text { Laju } \\
\text { Perub. } \\
\text { Luas } \\
\text { Lahan } \\
\text { Pertanian }\end{array}$ & $\begin{array}{c}\text { Perubaha } \\
\text { n Indeks } \\
\text { Entropy } \\
\text { Theil }\end{array}$ & $\begin{array}{c}\text { Laju } \\
\text { Perub. } \\
\text { Luas } \\
\text { Lahan } \\
\text { Pertanian }\end{array}$ & $\begin{array}{c}\text { Perub. } \\
\text { Indeks } \\
\text { Entropy } \\
\text { Theil }\end{array}$ \\
\hline 1. & Bergas & $\begin{array}{c}\text { SWP- } \\
1\end{array}$ & - & - & $-4,26 \%$ & 0,004 & $3,11 \%$ & 0,034 & $-33,92 \%$ & $-0,020$ \\
\hline 2. & Pringapus & $\begin{array}{c}\text { SWP- } \\
1\end{array}$ & - & - & $-4,72 \%$ & $-0,005$ & $3,03 \%$ & 0,001 & $6,26 \%$ & 0,003 \\
\hline 3. & $\begin{array}{l}\text { Ungaran } \\
\text { Barat }\end{array}$ & $\begin{array}{c}\text { SWP- } \\
1\end{array}$ & - & - & $-7,67 \%$ & 0,005 & $2,76 \%$ & 0,035 & $-4,79 \%$ & $-0,037$ \\
\hline 4. & $\begin{array}{l}\text { Ungaran } \\
\text { Timur }\end{array}$ & $\begin{array}{c}\text { SWP- } \\
1\end{array}$ & - & - & $-1,72 \%$ & $-0,013$ & $9,20 \%$ & 0,007 & $-38,43 \%$ & 0,003 \\
\hline 5. & Ambarawa & $\begin{array}{c}\text { SWP- } \\
2 \\
\end{array}$ & - & - & $-53,05 \%$ & $-0,012$ & $3,30 \%$ & $-0,034$ & $-25,92 \%$ & $-0,013$ \\
\hline 6. & Bandungan & $\begin{array}{c}\text { SWP- } \\
2\end{array}$ & - & - & $-2,37 \%$ & 0,001 & $3,39 \%$ & $-0,003$ & $-6,65 \%$ & 0,001 \\
\hline 7. & Banyubiru & $\begin{array}{c}\text { SWP- } \\
2 \\
\end{array}$ & - & - & $-3,40 \%$ & 0,0002 & $2,63 \%$ & 0,0001 & $-27,27 \%$ & 0,0033 \\
\hline 8. & Bawen & $\begin{array}{c}\text { SWP- } \\
2\end{array}$ & - & - & $-1,31 \%$ & $-0,033$ & $3,17 \%$ & $-0,008$ & $-4,44 \%$ & 0,008 \\
\hline 9. & Jambu & $\begin{array}{c}\text { SWP- } \\
2\end{array}$ & - & - & $5,39 \%$ & 0,003 & $-0,002 \%$ & 0,001 & $-2,39 \%$ & $-0,002$ \\
\hline 10. & Sumowono & $\begin{array}{c}\text { SWP- } \\
2\end{array}$ & - & - & $-0,02 \%$ & $-0,001$ & $-0,002 \%$ & $-0,001$ & $-4,65 \%$ & 0,004 \\
\hline 11. & Tuntang & $\begin{array}{c}\text { SWP- } \\
2 \\
\end{array}$ & - & - & $-2,51 \%$ & 0,002 & $2,37 \%$ & 0,004 & $-8,65 \%$ & $-0,001$ \\
\hline 12. & Bancak & $\begin{array}{c}\text { SWP- } \\
3\end{array}$ & - & - & $-4,96 \%$ & 0,001 & $3,48 \%$ & $-0,022$ & $-1,82 \%$ & $-0,0004$ \\
\hline 13. & Bringin & $\begin{array}{c}\text { SWP- } \\
3\end{array}$ & - & - & $-0,48 \%$ & 0,004 & $2,70 \%$ & $-0,006$ & $-3,26 \%$ & $-0,001$ \\
\hline 14. & Getasan & $\begin{array}{c}\text { SWP- } \\
3 \\
\end{array}$ & - & - & $-1,80 \%$ & 0,013 & $-0,0002 \%$ & $-0,045$ & $-51,41 \%$ & 0,004 \\
\hline 15. & Kaliwungu & $\begin{array}{c}\text { SWP- } \\
3\end{array}$ & - & - & $0,81 \%$ & $-0,0002$ & $4,52 \%$ & 0,0081 & $-25,31 \%$ & 0,0201 \\
\hline 16. & Pabelan & $\begin{array}{c}\text { SWP- } \\
3\end{array}$ & - & - & $-0,42 \%$ & $-0,0002$ & $2,80 \%$ & 0,0278 & $-7,30 \%$ & $-0,0173$ \\
\hline 17. & Suruh & $\begin{array}{c}\text { SWP- } \\
3\end{array}$ & - & - & $-2,46 \%$ & $-0,0003$ & $2,23 \%$ & 0,0054 & $-13,37 \%$ & 0,0022 \\
\hline 18. & Susukan & $\begin{array}{c}\text { SWP- } \\
3\end{array}$ & - & - & $-2,80 \%$ & 0,0002 & $4,02 \%$ & 0,0025 & $5,57 \%$ & 0,0030 \\
\hline 19. & Tengaran & $\begin{array}{c}\text { SWP- } \\
3\end{array}$ & - & - & $-4,19 \%$ & 0,007 & $2,33 \%$ & 0,003 & $-17,03 \%$ & $-0,001$ \\
\hline
\end{tabular}

Sumber : BPS Kab. Semarang, Kabupaten Dalam Angka, Kecamatan Dalam Angka dan PDRB Kecamatan Tahun 2009-2012 (diolah)

Jambu, dan Kecamatan Pringapus. Karakteristik Pengaruh Jumlah TenaSedangkan pada kawasan agropoli- ga Kerja Sektor Pertanian Terhadap tan, hubungan positif laju perubahan Ketimpangan Antar Wilayah pada Sekluas lahan dengan perubahan nilai in- tor Pertanian di Kabupaten Semarang deks ketimpangan wilayah sektor pertanian paling banyak terjadi di Kecamatan Pabelan dan Kecamatan Jambu.

Tahun 2008-2011

Melalui pengujian pada kasus sektor pertanian di Kabupaten Semarang 
dalam kurun waktu 2008-2011 menunjukkan bahwa jumlah tenaga kerja sektor pertanian berpengaruh negatif tidak signifikan terhadap indeks ketimpangan wilayah (indeks Entropy Theil). Dengan demikian, adanya penambahan/bertambahnya tenaga kerja sektor pertanian per kecamatan akan berpotensi menurunkan ketimpangan wilayah sektor pertanian dan demikian pula sebaliknya, namun pengaruhnya dinilai tidak akan berdampak secara signifikan.

Tidak signifikannya pengaruh perbedaan jumlah tenaga kerja dalam menurunkan ketimpangan antar wilayah pada sektor pertanian di Kabupaten Semarang adalah sesuai dengan perkiraan sebelumnya yang didasarkan atas pendapat Charles-Coll. Sedangkan jika mengacu pada teori Lewis (Kuncoro, 2010:110-111), ketidaksignifikanan pengaruh perbedaan jumlah tenaga kerja dalam menurunkan ketimpangan antar wilayah pada sektor pertanian di Kabupaten Semarang dapat dimungkinkan terjadi karena situasi surplus tenaga kerja sektor pertanian yang umum dialami di mayoritas negara berkembang mengakibatkan produk marjinal tenaga kerja sektor pertanian bernilai nol.

Pada kondisi tersebut fungsi produksi pada sektor pertanian dianggap telah sampai pada tingkat berlakunya law of diminishing return. Keadaan ini mengakibatkan penambahan input tenaga kerja sektor pertanian justru akan menurunkan total produksi sehingga dapat diperkirakan

Tabel 12

Diminishing Marginal Productivity, Diminishing Of Return, Dan Ketimpangan Antar Wilayah Sektor Pertanian Di Kabupaten Semarang Tahun 2008-2011

\begin{tabular}{|c|c|c|c|c|c|}
\hline \multirow{2}{*}{ Parameter } & \multicolumn{4}{|c|}{ Tahun / (\%) } & \multirow{2}{*}{$\begin{array}{c}\text { Rata-rata } \\
(\%)\end{array}$} \\
\hline & 2008 & 2009 & 2010 & 2011 & \\
\hline Penyerapan Tenaga Kerja & 29,67 & 36,50 & 35,89 & 35,89 & 34,49 \\
\hline Kontribusi PDRB & 12,99 & 13,09 & 12,75 & 12,57 & 12,85 \\
\hline PDRB per Kapita (Ribu Rp.) & $4.594,78$ & $3.779,97$ & $3.958,01$ & $4.101,79$ & $4.108,64$ \\
\hline Indeks Entropy Theil* & 0,21 & 0,21 & 0,35 & 0,36 & 0,283 \\
\hline
\end{tabular}

Sumber : BPS Kab. Semarang, Kabupaten Dalam Angka, PDRB Sektoral Tahun 20092012 (diolah) akan menurunkan derajat ketimpangan antar wilayah pada sektor pertanian.

Sementara di sisi lain, akibat proporsi input tenaga kerja yang terlalu besar maka pengurangan jumlah tenaga kerja yang dipekerjakan di sektor pertanian juga tidak akan mengurangi tingkat produksi yang ada. Dalam keadaan yang semacam ini dapat diasumsikan pangsa semua pekerja terhadap output yang dihasilkan adalah sama. Sehingga dengan besaran output antar wilayah yang tidak jauh berbeda, maka dengan sendirinya penurunan derajat ketimpangan antar wilayah pada sektor pertanian di Kabupaten Semarang yang diakibatkan oleh penambahan input tenaga kerja sektor pertanian menjadi tidak signifikan.

Tidak signifikannya pengaruh jumlah tenaga kerja sektor pertanian terhadap penurunan ketimpangan wilayah pada sektor pertanian di Kabupaten Semarang dapat dijelaskan dengan menggunakan bantuan tabel 12.

Berdasarkan tabel 12 di atas dapat diketahui bahwa sektor pertanian di Kabupaten Semarang telah mengalami kejenuhan produksi sehingga menyebabkan keunggulan input berupa besarnya penyerapan tenaga kerja tidak berdampak signifikan, baik dalam memberikan kontribusi terhadap pembentukan total PDRB, maupun dalam pembentukan output PDRB per kapita yang dihasilkan oleh petani. 
Untuk membantu menjelaskan secara lebih mendalam mengenai pengaruh jumlah tenaga kerja sektor pertanian terhadap ketimpangan antar wilayah pada sektor pertanian di Kabupaten Semarang dalam kurun waktu 2008-2011, maka dapat dilakukan analisis silang (kontijensi) yang membandingkan antara laju perubahan jumlah tenaga kerja sektor pertanian dengan perubahan nilai indeks ketimpangan wilayah per kecamatan sebagaimana pada tabel 13 berikut :
Melalui tabel kontijensi di atas secara jelas dapat terlihat ketidaksignifikanan hubungan antara laju perubahan jumlah tenaga kerja sektor pertanian dengan perubahan nilai indeks ketimpangan wilayah sektor pertanian di Kabupaten Semarang. Terutama di tahun 2010, ketika laju perubahan jumlah tenaga kerja menurun secara drastis hampir di seluruh wilayah kecamatan, namun perubahan tersebut tidak memberikan pengaruh signifikan terhadap nilai indeks ketimpangan wilayah.

Tabel 13

Perbandingan Laju Perubahan Jumlah Tenaga Kerja Sektor Pertanian Dan Perubahan Nilai Indeks Ketimpangan Wilayah (Entropy Theil) Sektor Pertanian Per Kecamatan Di Kabupaten Semarang Tahun 2008-2011

\begin{tabular}{|c|c|c|c|c|c|c|c|c|c|c|}
\hline \multirow[b]{2}{*}{ No. } & \multirow[b]{2}{*}{ Kecamatan } & \multirow[b]{2}{*}{ SWP } & \multicolumn{2}{|c|}{2008} & \multicolumn{2}{|c|}{2009} & \multicolumn{2}{|c|}{2010} & \multicolumn{2}{|c|}{2011} \\
\hline & & & $\begin{array}{c}\text { Laju } \\
\text { Perub. } \\
\text { Jumlah } \\
\text { Naker } \\
\text { Pertanian }\end{array}$ & $\begin{array}{c}\text { Perub. } \\
\text { Indeks } \\
\text { Entropy } \\
\text { Theil }\end{array}$ & $\begin{array}{c}\text { Laju } \\
\text { Perub. } \\
\text { Jumlah } \\
\text { Naker } \\
\text { Pertanian }\end{array}$ & $\begin{array}{c}\text { Perub. } \\
\text { Indeks } \\
\text { Entropy } \\
\text { Theil }\end{array}$ & $\begin{array}{c}\text { Laju } \\
\text { Perub. } \\
\text { Jumlah } \\
\text { Naker } \\
\text { Pertanian }\end{array}$ & $\begin{array}{c}\text { Perub. } \\
\text { Indeks } \\
\text { Entropy } \\
\text { Theil }\end{array}$ & $\begin{array}{c}\text { Laju } \\
\text { Perub. } \\
\text { Jumlah } \\
\text { Naker } \\
\text { Pertanian }\end{array}$ & $\begin{array}{c}\text { Perub. } \\
\text { Indeks } \\
\text { Entropy } \\
\text { Theil }\end{array}$ \\
\hline 1. & Bergas & SWP-1 & - & - & $1,801 \%$ & 0,004 & $-42,219 \%$ & 0,034 & $1,048 \%$ & $-0,020$ \\
\hline 2. & Pringapus & SWP-1 & - & - & $14,613 \%$ & $-0,005$ & $-50,742 \%$ & 0,001 & $0,683 \%$ & 0,003 \\
\hline 3. & $\begin{array}{l}\text { Ungaran } \\
\text { Barat }\end{array}$ & SWP-1 & - & - & $0,000 \%$ & 0,005 & $-63,467 \%$ & 0,035 & $1,314 \%$ & $-0,037$ \\
\hline 4. & $\begin{array}{l}\text { Ungaran } \\
\text { Timur }\end{array}$ & SWP-1 & - & - & $27,952 \%$ & $-0,013$ & $118,004 \%$ & 0,007 & $0,577 \%$ & 0,003 \\
\hline 5. & Ambarawa & SWP-2 & - & - & $1,573 \%$ & $-0,012$ & $-45,224 \%$ & $-0,034$ & $0,496 \%$ & $-0,013$ \\
\hline 6. & Bandungan & SWP-2 & - & - & $-5,879 \%$ & 0,001 & $-6,940 \%$ & $-0,003$ & $1,016 \%$ & 0,001 \\
\hline 7. & Banyubiru & SWP-2 & - & - & $0,817 \%$ & 0,0002 & $-46,115 \%$ & 0,0001 & $0,551 \%$ & 0,0033 \\
\hline 8. & Bawen & SWP-2 & - & - & $26,133 \%$ & $-0,033$ & $-15,559 \%$ & $-0,008$ & $0,798 \%$ & 0,008 \\
\hline 9. & Jambu & SWP-2 & - & - & $0,231 \%$ & 0,003 & $-59,573 \%$ & 0,001 & $0,764 \%$ & $-0,002$ \\
\hline 10. & Sumowono & SWP-2 & - & - & $9,847 \%$ & $-0,001$ & $-31,544 \%$ & $-0,001$ & $0,548 \%$ & 0,004 \\
\hline 11. & Tuntang & SWP-2 & - & - & $-0,117 \%$ & 0,002 & $-78,808 \%$ & 0,004 & $0,624 \%$ & $-0,001$ \\
\hline 12. & Bancak & SWP-3 & - & - & $30,783 \%$ & 0,001 & $-28,272 \%$ & $-0,022$ & $0,157 \%$ & $-0,0004$ \\
\hline 13. & Bringin & SWP-3 & - & - & $-5,738 \%$ & 0,004 & $-9,206 \%$ & $-0,006$ & $0,270 \%$ & $-0,001$ \\
\hline 14. & Getasan & SWP-3 & - & - & $0,019 \%$ & 0,013 & $-3,130 \%$ & $-0,045$ & $0,669 \%$ & 0,004 \\
\hline 15. & Kaliwungu & SWP-3 & - & - & $1,015 \%$ & $-0,0002$ & $-47,942 \%$ & 0,0081 & $-0,013 \%$ & 0,0201 \\
\hline 16. & Pabelan & SWP-3 & - & - & $5,252 \%$ & $-0,0002$ & $-63,564 \%$ & 0,0278 & $0,370 \%$ & $-0,0173$ \\
\hline 17. & Suruh & SWP-3 & - & - & $6,312 \%$ & $-0,0003$ & $103,680 \%$ & 0,0054 & $0,141 \%$ & 0,0022 \\
\hline 18. & Susukan & SWP-3 & - & - & $7,434 \%$ & 0,0002 & $-59,938 \%$ & 0,0025 & $0,109 \%$ & 0,0030 \\
\hline 19. & Tengaran & SWP-3 & - & - & $-20,966 \%$ & 0,007 & $-78,011 \%$ & 0,003 & $0,319 \%$ & $-0,001$ \\
\hline
\end{tabular}

Sumber : BPS Kab. Semarang, Kabupaten Dalam Angka, Kecamatan Dalam Angka dan PDRB Kecamatan Tahun 2009-2012 (diolah) 
Pada tabel kontijensi juga nampak hubungan laju perubahan jumlah tenaga kerja sektor pertanian dengan perubahan nilai indeks ketimpangan wilayah sektor pertanian per kecamatan yang secara mayoritas sifatnya berlawanan arah/ negatif. Dimana dari 57 (lima puluh tujuh) pasang data yang diperbandingkan, 34 (tiga puluh empat) diantaranya $(59,64 \%)$ menunjukkan kecocokan pola dalam sifat/ arah hubungan.

Sebagaimana terlihat pada tabel 13, di tahun 2009 hubungan negatif laju perubahan jumlah tenaga kerja sektor pertanian dengan perubahan nilai indeks ketimpangan wilayah sektor pertanian terlihat berlaku di 12 kecamatan, kemudian di tahun 2010 pola hubungan tersebut terlihat berlaku di 12 kecamatan namun dengan lokus yang berbeda, sedangkan di tahun 2011 turun menjadi 10 kecamatan.

Dari seluruh kecamatan, hanya terdapat empat diantaranya yang menunjukkan adanya hubungan negatif antara laju perubahan jumlah tenaga kerja sektor pertanian dengan perubahan nilai indeks ketimpangan wilayah sektor pertanian secara konsisten dari tahun ke tahun, yaitu Kecamatan Tengaran, Kecamatan Kaliwungu, Kecamatan Pabelan, dan Kecamatan Tuntang. Sedangkan pada kawasan agropolitan hubungan negatif tersebut relatif dialami di Kecamatan Kaliwungu, Suruh, Pabelan, Jambu, dan Bringin.

Sementara jika ditinjau berdasarkan kelompok Satuan Wilayah Pengembangan, dapat diketahui bahwa hubungan negatif laju perubahan jumlah tenaga kerja sektor pertanian dengan perubahan nilai indeks ketimpangan wilayah sektor pertanian di Kabupaten Semarang umumnya banyak terjadi pada wilayah SWP-3.

Disamping itu, pembuktian pengaruh negatif jumlah tenaga kerja sektor pertanian terhadap ketimpangan antar wilayah pada sektor pertanian di Kabupaten Semarang juga dapat dilakukan dengan bantuan analisis kontijensi yang memperbandingkan antara indeks spesialisasi tenaga kerja sektor pertanian dengan indeks ketimpangan wilayah sektor pertanian per kecamatan. Melalui analisis ini dapat diduga bahwa wilayah-wilayah kecamatan basis tenaga kerja pertanian (nilai indeks spesialisasi $\geq 1,00$ ) adalah berpotensi menurunkan ketimpangan antar wilayah pada sektor pertanian di Kabupaten Semarang.

Adapun dalam pengujian kebenaran dugaan tersebut, terlebih dahulu harus disusun tabel kontijensi untuk melihat potensi ketimpangan wilayah sektor pertanian yang ditimbulkan/dimiliki kecamatan basis tenaga kerja sektor pertanian yang disandingkan dengan rata-rata nilai distribusi ketimpangan wilayah berdasarkan indeks Entropy Theil sektor pertanian.

Analisis kontijensi berdasarkan tabel 14 menunjukkan mayoritas kecamatan basis tenaga kerja pertanian berpotensi mengurangi ketimpangan antar wilayah. Dengan demikian, dugaan bahwa wilayahwilayah kecamatan basis tenaga kerja pertanian berpotensi mengurangi ketimpangan antar wilayah adalah dapat dibenarkan.

Sebagaimana data pada tabel 14 , terlihat bahwa dari 12 kecamatan basis tenaga kerja pertanian, terdapat sebanyak 8 (delapan) diantaranya yang menunjukkan adanya konsistensi potensi basis tenaga kerja sektor pertanian dalam mengurangi ketimpangan wilayah dari tahun ke tahun, yaitu pada Kecamatan Tengaran, Kecamatan Susukan, Kecamatan Suruh, Kecamatan Banyubiru, Kecamatan Jambu, Kecamatan Sumowono, Kecamatan Bandungan, dan Kecamatan Bringin.

Dengan kondisi mayoritas wilayah kecamatan basis tenaga kerja pertanian yang cenderung berpotensi mengurangi ketimpangan antar wilayah menunjukkan adanya gejala paradoks pada sektor pertanian. Karena secara logika surplus tenaga kerja pada kecamatan basis seharusnya justru berpotensi meningkatkan ketimpa 
Tabel 14

Rata-Rata Indeks Spesialisasi Dan Indeks Entropy Theil Sektor Pertanian Per Kecamatan Di Kabupaten Semarang Tahun 2008-2011

\begin{tabular}{|c|c|c|c|c|}
\hline No. & Kecamatan & SWP & $\begin{array}{c}\text { Rata-Rata } \\
\text { Indeks } \\
\text { Spesialisasi }\end{array}$ & $\begin{array}{c}\text { Rata-Rata Nilai } \\
\text { Indeks Entropy } \\
\text { Theil }\end{array}$ \\
\hline 1. & Bergas & SWP-1 & 0,48 & 0,034 \\
\hline 2. & Pringapus & SWP-1 & 0,82 & $-0,003$ \\
\hline 3. & Ungaran Barat & SWP-1 & 0,33 & 0,044 \\
\hline 4. & Ungaran Timur & SWP-1 & 0,48 & 0,001 \\
\hline 5. & Ambarawa & SWP-2 & 0,47 & 0,038 \\
\hline 6. & Bandungan & SWP-2 & 1,37 & $-0,012$ \\
\hline 7. & Banyubiru & SWP-2 & 1,35 & $-0,007$ \\
\hline 8. & Bawen & SWP-2 & 0,61 & 0,015 \\
\hline 9. & Jambu & SWP-2 & 1,14 & $-0,007$ \\
\hline 10. & Sumowono & SWP-2 & 1,75 & $-0,003$ \\
\hline 11. & Tuntang & SWP-2 & 0,95 & $-0,005$ \\
\hline 12. & Bancak & SWP-3 & 1,65 & 0,008 \\
\hline 13. & Bringin & SWP-3 & 1,51 & $-0,009$ \\
\hline 14. & Getasan & SWP-3 & 1,79 & 0,004 \\
\hline 15. & Kaliwungu & SWP-3 & 1,18 & 0,007 \\
\hline 16. & Pabelan & SWP-3 & 1,05 & 0,008 \\
\hline 17. & Suruh & SWP-3 & 1,24 & $-0,013$ \\
\hline 18. & Susukan & SWP-3 & 1,32 & $-0,006$ \\
\hline 19. & Tengaran & SWP-3 & 1,06 & $-0,005$ \\
\hline
\end{tabular}

Sumber : BPS Kab. Semarang, Kecamatan Dalam Angka dan PDRB Kecamatan Tahun 2009-2012 (diolah)

ngan wilayah, mengingat semakin banyak tenaga kerja akan semakin meningkatkan total produktivitas wilayah basis sehingga secara aggregat akan memiliki tingkat produktivitas yang lebih tinggi daripada wilayah non-basis.

Atau dengan kata lain gejala paradoks pada sektor pertanian ini menunjukkan rata-rata tingkat produktivitas yang rendah diseluruh kecamatan, sehingga mengakibatkan relatif kecilnya kesenjangan/ketimpangan produktivitas antara wilayah kecamatan basis dengan wilayah kecamatan non-basis.

\section{Penutup}

Berdasarkan hasil penelitian, maka dapat diperoleh ditarik kesimpulan bahwa ketersediaan anugerah lokal (local endowments) yang diwakili oleh luas lahan pertanian dan jumlah tenaga kerja sektor pertanian dapat mempengaruhi terjadinya ketimpangan wilayah pada sektor pertanian di Kabupaten Semarang. Namun demikian pengujian secara parsial membuktikan perbedaan luas lahan pertanian lebih kuat pengaruhnya karena berpengaruh positif dan signifikan terhadap ketimpangan antar wilayah pada sektor pertanian di Kabupaten Semarang. Atau dengan kata lain dapat dinyatakan bahwa selama periode 2008-2011, adanya penambahan 
luas lahan pertanian akan semakin signifikan menambah ketimpangan antar wilayah pada sektor pertanian di Kabupaten Semarang. Sementara pengujian secara parsial pada perbedaan jumlah tenaga kerja sektor pertanian ternyata hasilnya berpengaruh negatif dan tidak signifikan terhadap ketimpangan antar wilayah pada sektor pertanian di Kabupaten Semarang. Atau dengan kata lain dapat dinyatakan bahwa selama periode 2008-2011, adanya penambahan jumlah tenaga kerja sektor pertanian akan tidak signifikan mengurangi ketimpangan antar wilayah pada sektor pertanian di Kabupaten Semarang.

Adapun sesuai dengan analisis hasil penelitian, maka dapat direkomendasikan sejumlah saran yang diharapkan akan bermanfaat bagi perbaikan kebijakan pembangunan sektor pertanian di Kabupaten Semarang, yaitu antara lain:

Pertama, Karena pengaruh perbedaan luas lahan pertanian terhadap ketimpangan antar wilayah pada sektor pertanian sifatnya lebih signifikan jika dibandingkan dengan perbedaan jumlah tenaga kerja sektor pertanian, maka upaya penanganan ketimpangan antar wilayah pada sektor pertanian di Kabupaten Semarang disarankan akan lebih efektif jika difokuskan pada kebijakan pengendalian pemanfaatan lahan pertanian. Khususnya di wilayah SWP-2 dan SWP-3 yang potensi ketimpangan sektor pertaniannya sangat rentan terhadap pengaruh dari perubahan luas lahan pertanian.

Oleh karena itu, sudah sepatutnya pemerintah Kabupaten Semarang melakukan perlindungan terhadap areal lahan pertanian dari proses terjadinya konversi atau alih fungsi lahan. Perlindungan tersebut dilakukan dengan jalan mengendalikan konversi atau alih fungsi lahan agar tidak dilakukan pada lahan-lahan pertanian subur yang dapat mengganggu produktivitas sektor pertanian. Dengan demikian tingkat ketimpangan wilayah pada sektor pertanian di Kabupaten Semarang akan tetap ter- jaga pada level yang "wajar" namun tidak mengorbankan sisi produktivitasnya.

Kedua, Ketidaksignifikanan pengaruh jumlah tenaga kerja sektor pertanian terhadap ketimpangan antar wilayah pada sektor pertanian sebaiknya dapat mendorong pemerintah Kabupaten Semarang untuk melakukan reorientasi kebijakan dalam pendayagunaan potensi tenaga kerja sektor pertanian. Cara pandang lama terhadap tenaga kerja sektor pertanian harus diubah. Dalam hal ini, banyaknya jumlah tidak boleh lagi dianggap sebagai beban, namun harus dipandang sebagai satu kekuatan.

Hal tersebut sangat dimungkinkan mengingat sejatinya sektor pertanian merupakan representasi dari wujud sektor ekonomi kerakyatan yang dapat menyerap banyak tenaga kerja. Sehingga apabila potensinya benar-benar diberdayakan secara maksimal maka akan sangat berpotensi dalam mengurangi jumlah pengangguran, menurunkan angka kemiskinan, dan dapat mereduksi ketimpangan antara wilayah maju dengan wilayah tertinggal.

Oleh karena itu, Pemerintah Kabupaten Semarang harus mampu menjaga motivasi para pekerja sektor pertanian agar tetap konsisten pada jalur bertani. Dan, disamping itu Pemerintah Kabupaten Semarang juga harus mampu untuk selalu berperan aktif dalam mengupayakan peningkatan kualitas tenaga kerja sektor pertanian sehingga produktivitasnya tidak tertinggal jauh dengan produktivitas pekerja pada sektor-sektor ekonomi lainnya.

Ketiga, Melalui nilai intersep masing-masing kecamatan dapat diketahui potensi penyebab ketimpangan tertinggi terdapat di SWP-1 yang notabene tidak satupun bagian wilayah kecamatannya berstatus sebagai kawasan agropolitan. Sementara dari 10 (sepuluh) kecamatan yang telah ditetapkan sebagai kawasan agropolitan, hanya terdapat 3 (tiga) diantaranyayang berpotensi positif atau memiliki karakteristik menambah 
ketimpangan wilayah.

Keadaan tersebut tentunya menunjukkan kinerja produktivitas kawasan agropolitan belum dapat mencerminkan keunggulan kinerja komparatif sektor pertanian jika dibandingkan dengan wilayah-wilayah non-kawasan agropolitan. Oleh sebab itu, kiranya perlu dilakukan evaluasi ulang terhadap kebijakan penataan dan pengembangan kawasan agropolitan di Kabupaten Semarang. Sehingga diharapkan hasil kebijakan pembentukan kawasan agropolitan akan benar-benar dapat mencerminkan efektivitas pencapaian tujuan sesuai dengan cita-cita yang mendasari pembentukan kawasan tersebut di wilayah Kabupaten Semarang.

\section{Daftar Pustaka}

Adisasmita, Rahardjo. 2013. Teori-Teori Pembangunan Ekonomi. Graha IImu. Yogyakarta.

Charles-Coll, Jorge A. 2011. Understanding Income Inequality: Concept, Causes and Measurement. International Journal of Economics and Management Sciences 1 (3): 17-28.

Emilia dan Imelia. 2006. Modul Ekonomi Regional. Jurusan Ilmu Ekonomi Fakultas Ekonomi Universitas Jambi. Jambi.

Keil, Jens-Philipp. 2010. Chinas "Go West" Policy zur Minderung der ausgeprägten Ost-West-Disparitäten und zur Verbesserung des Investitionsklimas in Westchina: Genese, Ziele, Maßnahmen und Effekte-Attraktivität der westchinesischen Provinzen als Investitionsstandort für ausländische Unternehmen-. Dissertation. der naturwissenschaftlichen Fachbereiche der Justus-Liebig-Universität Gießen.

Kuncoro, Mudrajad. 2010. Dasar-Dasar Ekonomika Pembangunan. (Edisi 5). UPP STIM YKPN. Yogyakarta.

Machfudz, Masyhuri. 2007. Dasar-Dasar
Ekonomi Mikro. Prestasi Pustaka Publisher. Jakarta.

Nijkamp, Peter 2009. Regional Development as Self-Organized Converging Growth dalam World Bank. 2009. Spatial Disparities and Development Policy. The World Bank.

Peraturan Daerah Kabupaten Semarang Nomor 6 Tahun 2011 Tentang Rencana Tata Ruang Wilayah (RTRW) Kabupaten Semarang Tahun 2011-2031.

Purwanto, Erwan A. dan Dyah Ratih Sulistyastuti 2011. Metode Penelitian Kuantitatif Untuk Administrasi Publik dan Masalah-Masalah Sosial. (Edisi Pertama, Cetakan Kedua). Gava Media. Yogyakarta.

Sjafrizal. 2008. Ekonomi Regional, Teori dan Aplikasi. Baduose Media. Padang.

Sjafrizal. 2012. Ekonomi Wilayah dan Perkotaan. Rajawali Pers. Jakarta.

Soegiarto, Eddy dan Mardyono. 2011. Pengantar Teori Ekonomi. Mahkota Ilmu. Banten.

Subandi. 2008. Sistem Ekonomi Indonesia. (Cetakan Keempat). Alfabeta. Bandung.

Sukirno, Sadono. 1985. Ekonomi Pembangunan Proses, Masalah, dan Dasar Kebijaksanaan. Lembaga Penerbit Fakultas Ekonomi Universitas Indonesia. Jakarta.

Tambunan, Tulus T.H. 2001. Transformasi Ekonomi di Indonesia: Teori \& Penemuan Empiris. Salemba Empat. Jakarta.

Todaro, Michael P. dan Stephen C. Smith. 2006. Pembangunan Ekonomi Jilid 1. (Edisi Kesembilan). Erlangga. Jakarta. 